\author{
JAZMÍN RINCÓN \\ FACULTAD DE FILOSOFÍA Y LETRAS, UNAM
}

\title{
Los versos instrumentales de Ignacio Jerusalem y Stella: vestigios de un discurso sonoro en la Catedral de México
}

\section{Los versos para órgano y el contrapunto improvisado}

the chief use made of [the organ], was to play over the chant before it was sung, all through the Psalms. Upon enquiring of a young abbé, whom I took with me as a nomenclator, what this was called? C'est prose, "Tis prosing," he said. And it should seem as if our word prosing came from this dull and heavy manner of recital.

Charles Burney, I77I. ${ }^{\mathrm{I}}$

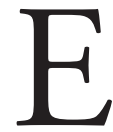

1 término versillo ${ }^{2}$ o verso para órgano, exclusivo del rito litúrgico de la Iglesia católica apostólica romana, se suele utilizar para nombrar breves improvisaciones o composiciones que solían ejecutarse en sustitución de uno o varios versos de un salmo, himno, cántico u otro texto perteneciente a

I. Charles Burney, The Present State of Music in France an Italy (I77I), "el uso principal del órgano era tocar de acuerdo con el canto de los Salmos, antes de que éstos fuesen entonados. Así, al preguntarle a un joven abate, a quien llevé conmigo como traductor, ¿cómo se llama esto? C'est prose, 'esto es prosa', dijo. Y tal parecía que nuestra palabra prosa proviniera de esta torpe y pesada forma de recitar" [traducción de la autora].

2. La terminología en algunos países católicos: versetti per organo en italiano, verset en inglés y francés, y verso para órgâo en portugués. 
la Liturgia de las Horas. ${ }^{3}$ Así, se suplía con el sonido del órgano la melodía que expresaba el texto mediante la palabra cantada, y de esta forma quedaba la mitad de este último truncada, aspecto que causó en un principio mucha reticencia y confusión por parte de los fieles que continuamente murmuraban el texto del salmo por encima de la parte del órgano. ${ }^{4}$ Por todo esto, el vocabulario latino alternatim (alternadamente) se usa comúnmente para nombrar dicha alternancia entre el canto de las fórmulas melódicas existentes en el repertorio del canto eclesiástico y la interpretación del órgano u otros instrumentos. ${ }^{5}$

Mucho se puede deducir, aunque no saber con certeza, acerca de qué tanto influía el texto utilizado en la estructura de los versos para órgano o versillos. De acuerdo con los versos para órgano que sobreviven en nuestros días, sabemos en general que el organista realizaba la improvisación de dicha práctica alternatim ${ }^{6}$ de cada una de la siguientes maneras o en combinación: a) citando literalmente el cantus firmus con el cual el órgano alternaba; b) creando temas inspirados por el ritmo de las palabras; c) de acuerdo con el registro en que el canto llano se interpretaba.

3. Desde el punto de vista literario, los salmos y los cánticos tienen la misma estructura, mientras que los himnos no se constituyen por versos, sino por estrofas de cuatro o más versos, generalmente octosílabos. A los versos salmódicos se les suele implantar la forma musical del recitativo, mientras que los himnos tienen una conformación melódica variada que se repite en cada estrofa.

4. Cabe mencionar que el proceso de aceptación e institucionalización de los versos o versillos por parte de las autoridades eclesiásticas llegó a tomar incluso siglos para que este tipo de alternatim, que sustituía en un principio la parte cantada por la interpretación del órgano, formara parte de la liturgia (Keyboard Music, before I70o, ed. Alexander Silbiger [Nueva York: Routledge, 2004], 97). Después de todo, el sonido solo del órgano resultaba demasiado abstracto junto a la palabra de Dios.

5. Previo a la aparición de la notación musical, con la siempre presente necesidad de instrucción y guía dentro de la Iglesia, el occidente cristiano había introducido un recurso que consistía en que dos grupos de cantantes, usualmente en oposición, interpretaran en alternancia una clave de lectura junto con los versículos del salmo. Es de dicha estructura llamada antífona que posteriormente el canto cristiano dio un paso general de la forma antifónica a la intercalar o, dicho de otra forma, de la alternancia vocal que dice y responde, a la introducción progresiva de un elemento no vocal que se intercala.

6. El término alternatim resulta sumamente vago: no estamos hablando de una forma musical y mucho menos de un género musical, sino de una práctica inherente a la liturgia y a la concepción católica del mundo, la idea del discurso en torno a Dios y la respuesta de los fieles, que además de formar parte de todo un contexto litúrgico cuya estructura solía cambiar de acuerdo con la ocasión, el tiempo y el lugar, no se limitaba a la oposición de polifonía con canto llano. 
DOI: http://dx.doi.org/10.22201/iie.18703062e.2014.105.2529

LOS VERSOS INSTRUMENTALES DE IGNACIO JERUSALEM

Uno de los muchos ejemplos de esta práctica lo tenemos en los contratos de los organistas del siglo XVII que Bruce Gustafson menciona en su artículo sobre la música para órgano en Francia, ${ }^{7}$ en donde existen cantidades de hasta 400 servicios en los que el organista participaba, los cuales podían llegar a demandar la interpretación de aproximadamente roo versos para órgano en un día. Este número testimonial tan vasto contrasta con el número de manuscritos y facsímiles de los mismos que han sobrevivido en el occidente católico. En la Nueva Espańa, dicha ausencia resulta extrema, pues un cuaderno de versos para órgano ${ }^{8}$ encontrado en la catedral de Oaxaca, y del cual no se sabe si perteneció a la monja sor María Clara del Santísimo Sacramento o si ella misma fue la autora, es hasta ahora el único sobreviviente directo de dichas tipologías organísticas. ${ }^{9}$ Sin embargo, rastros indirectos como los arrojados por las actas capitulares o las reglas de coro nos indican que desde un principio, en la Nueva España, este tipo de versos para órgano se interpretaba profusamente en las celebraciones litúrgicas. En la figura I se visualiza la intervención del órgano en la celebración de la

7. Bruce Gustafson, "France. Chapter Three", en Keyboard Music: Before I700 (Nueva York: Routledge, 2004), 97.

8. Cuaderno de tonos de maitines de sor María Clara del Santísimo Sacramento, ed. Calvert Johnson, ed. bilingüe, trad. Enrique de Esesarte, Calvert Johnson et al. (Carolina del Norte: Wayne Leupold Editions, 2005).

9. A diferencia de España, la literatura musical para órgano que ha sobrevivido de la época colonial se limita a tan sólo dos ejemplos: el Libro que contiene onze partidos del M. Dn. Joseph de Torres, documento que es una copia tardía del siglo xvinI perteneciente a la colección Sánchez Garza (Rubén Valenzuela, "El libro para órgano de Joseph de Torres: un estudio de autoría”, Heterofonía, núms. I20-I 2 I [enero-diciembre, I999]: 40-54), así como una tablatura para órgano (ca. I630), publicada en tres entregas por Gabriel Saldívar Silva (mencionada en el libro de Robert Stevenson, Music in Mexico: A Historical Survey [Nueva York: Thomas Y. Crowell, I968], I60-I62, y publicada por Gabriel Saldívar Silva: "Una tablatura mexicana", Revista Musical Mexicana 2, núms. 2-3 y 5 [abril, I942]: 36-39, 65-66 y I0-I I). Como explica Javier Marín López en su tesis doctoral, el hecho de que la música para teclado en la Nueva España sea tan escasa, habla también de la estructuración del propio archivo musical a lo largo del tiempo: "A diferencia de los maestros de capilla, los instrumentistas disponían de sus propios libros y no estaban obligados a dejarlos en la catedral, aunque en ocasiones el cabildo se interesó por su compra con la idea de ir formando un archivo, tal y como lo acredita la compra de libros con repertorio instrumental en I578, I635 y I745. La propiedad privada de estas fuentes instrumentales explica el bajo número de manuscritos para ministriles y libros para órgano conservados actualmente en las catedrales", Javier Marín López, "Música y músicos entre dos mundos. La Catedral de México y sus libros de polifonía, siglos XVI-XVIII", tesis doctoral, 3 vols. (Universidad de Granada, 2007), vol. I, 547. 
DOI: http://dx.doi.org/10.22201/iie.18703062e.2014.105.2529

Distribución de los cantos del Propio y del Ordinario de la misa

Cursivas: son las partes del Ordinario de la misa donde el órgano sustituía ya sea parte o el texto completo.

Texto normal: son las partes del Propio de la misa, variables según el tiempo litúrgico o la festividad.

Negritas: momentos en donde se utilizaba el órgano como instrumento solista e independiente

a) Primera parte de la misa — es la de los Catecúmenos, la cual constituye la parte catequística de la misa, donde los aspirantes a recibir el bautismo reciben instrucción con este fin, lo que la hace tener un carácter doctrinal. Ésta incluye:

I. Pieza inicial para solemnizar la entrada de los ministros de la celebración —aquí el uso del órgano, y de cualquier otro instrumento, estaba prohibido en los tiempos litúrgicos de Adviento y de Cuaresma.

2. Introito (canto variable propio de la fiesta) — la respuesta depende de cómo se empezó: si se canta en canto llano, suele alternarse con polifonía y viceversa.

3. Preces y absolución.

4. Kyrie eleison (versos organísticos alternativos).

5. Gloria in excelsis (versos organísticos alternativos).

6. Oración colecta.

7. Lectura bíblica.

8. Salmodia (cantos de reflexión sobre la lectura) —ésta incluye las siguientes partes según el tiempo litúrgico: Gradual y Aleluya en tiempo ordinario; Gradual y Tracto en tiempo de Cuaresma; dos aleluyas en tiempo de Pascua.

9. Lectura evangélica.

ıo. Homilía: exégesis de las lecturas.

I I. Credo (versos organísticos alternativos).

b) Segunda parte de la misa — es la de los fieles o de los bautizados, que por lo mismo, tenían el derecho a participar del sacrificio y de la comunión, gira en torno a la evocación de la última cena de Cristo con sus discípulos, con la consagración del pan y del vino-incluye:

I2. Ofertorio (pieza organística de ambientación o canto complementario).

I3. Oración sobre las ofrendas (Oración Secreta).

I4. Prefacio (con él se inicia el Canon de la misa).

I 5. Sanctus - Benedictus (versos organísticos alternativos).

16. Consagración (pieza organística de ambientación).

17. Agnus Dei (versos organísticos alternativos).

I8. Comunión (pieza organística de ambientación o canto complementario).

I9. Conclusión (pieza organística de salida).

I. Secciones donde el órgano intervenía en una misa (reconstrucción). 
DOI: http://dx.doi.org/10.22201/iie.18703062e.2014.105.2529

LOS VERSOS INSTRUMENTALES DE IGNACIO JERUSALEM

Ordinario de la misa con las partes donde participaba el órgano

Texto normal: el órgano sustituía una parte o todo el texto. También intervenciones solistas. Cursivas: canto de forma normal.

Negritas: el cantus firmus tenía que ser audible (la melodía tocada debía reconocerse a lo largo de la parte que había sido cantada).

I.

Kyrie eleison. Kyrie eleison. Kyrie eleison.

Christe eleison. Christe eleison. Christe eleison.

Kyrie eleison, Kyrie eleison. Kyrie eleison.

2.

Gloria in excelsis Deo (esta parte es cantada solo por el sacerdote).

Et in terra pax hominibus bonœ voluntatis.

Laudamus te. Benedicimus te. Adoramus te. Glorificamus te.

Gratias agimus tibi Procter magnam gloriam tuam.

Domine Deus, Rex cœlestis, Deus Pater omnipotens.

Domine Fili unigenite Jesu Christe.

Domine Deus, Agnus Dei, Filus Patris.

Qui tollis peccata mundi, miserere nobis.

Qui tollis peccata mundi suscite deprecationem nostram.

Qui sedes ad dexteram Patris, miserere nobis.

Quoniam tu solus sanctus.

Tu solus Dominus.

Tu solus altissimus, Jesu Christe.

Cum Sancto Spiritu.

In gloria Dei Patris, Amen.

3 .

Credo (sin órgano).

4 .

Sanctus. Sanctus, Sanctus, Dominus Deus Sabaoth.

Pleni sunt Coeli et terra gloria tua. Hosanna in excelsis.

Benedictus qui venit in nomine Domini. Hosanna in excelsis.

Canon (el sacerdote recita las palabras de la consagración).

Elevación (parte del canon).

5 .

Agnus Dei, qui tollis peccata mundi: miserere nobis.

Agnus Dei, qui tollis peccata mundi: miserere nobis.

Agnus Dei, qui tollis peccata mundi: dona nobis pacem.

Deo gratias (pieza para después de la despedida, ya no es parte del Agnus Dei).

Domine, salvum fac Regem, et exuadi nos in die quam invocaverimus te (canto devocional). Procesión (aquí no se tocaban versos sino una pieza grande como epílogo a toda la celebración).

2. Secciones instrumentales en los textos del Ordinario de la misa (reconstrucción). 
misa, ${ }^{10}$ mientras que en la figura 2 presento una reconstrucción que ejemplifica la alternancia de los versos para órgano que responde a un esquema teórico sujeto a pequeñas variantes temporales y geográficas.

El hecho de que la literatura sobreviviente de estas tipologías organísticas haya aparecido a partir del siglo XVI, precisamente en una época en la que el arte de tocar el órgano - y prácticamente cualquier instrumento- era sinónimo de improvisación, nos coloca frente a un aspecto crucial que revela la alternancia con textos salmódicos, tanto de versos organísticos improvisados y escritos, como — más tarde— de versos instrumentales; la tradición oral frente a la escritura musical reflejada en el siguiente posicionamiento: "improvisacióncomposición/memoria-escritura". ${ }^{\text {I }}$

Efectivamente, aunque algunas veces la concepción y enseñanza actual de la historia de la música del pasado nos haga olvidarlo, la música no es la escritura, sino un acto de interpretación que el ser humano lleva a cabo en la ejecución, la escucha y el análisis. Por lo mismo, el hecho de que la materia prima sean precisamente las fuentes musicales codificadas plantea una cuestión importante a considerar: al preservarse por medio de la tradición escrita, los versos para órgano e instrumentos pasaron por procesos similares, mas no iguales, a aquellos que se improvisaban a diario en grandes cantidades por los organistas locales de la iglesia con la función de ensamblar el ritual litúrgico. Dichos procesos, como los versos para órgano de maestros italianos, españoles y franceses, ${ }^{\mathrm{I2}}$ han dejado rastros y analogías estructurales muy significativas en los versos instrumentales, como es el caso muy específico del corpus sobreviviente en la Catedral de México que abarca los siglos XVIII y xix. Por todo esto, al hablar de los versos

Io. La idea de dicha reconstrucción está basada en parte en el artículo de Gustafson, Keyboard Music: Before I700, I00-I03, así como en trabajos realizados para el Seminario de Música Novohispana y del México Independiente del Instituto de Investigaciones Estéticas de la Universidad Nacional Autónoma de México, impartido por Juan Manuel Lara Cárdenas en enero de 2006.

II. Dicho posicionamiento, así como el tema memoria-escritura, ha sido abordado de manera específica y más ampliamente en las siguientes publicaciones: Anna Maria Busse Berger, Medieval Music and the Art of Memory (Berkeley: University of California Press, 2005); Giuseppe Fiorentino, "Folía". El origen de los esquemas armónicos entre tradición oral y transmisión escrita (Kassel: Reichenberger, 2013); Mary J. Carruthers, The Book of Memory: A Study of Memory in Medieval Culture (Cambridge University Press, 1990).

I2. Algunos de los compositores que escribieron versos para órgano son: Antonio de Cabezón, España, ( I 5 10-1 566), François Couperin, Francia, (I666-1733), Girolamo Frescobaldi, Italia, (I 583-I643), entre otros. 
DOI: http://dx.doi.org/10.22201/iie.18703062e.2014.105.2529

LOS VERSOS INSTRUMENTALES DE IGNACIO JERUSALEM

para órgano improvisados y de los versos para órgano e instrumentos que se conservan en manuscritos, nos encontramos en el umbral entre la tradición escrita y la oral de la música, donde además, la misma transferencia oral del repertorio de los salmos ha tenido un papel primordial en dichos procesos de desplazamiento, transmisión y modificación. Esto último me lleva a hacer algunas consideraciones históricas respecto a la práctica de la improvisación polifónica en los siglos XV y XVI, pues la misma improvisación sobre el cantus firmus formaba parte de la cultura musical occidental, confrontando y transformando así la tradición escrita de la música.

El término contrapunto, ${ }^{\mathrm{I} 3}$ cuya práctica se originó en el siglo XV y alcanzó un alto grado de desarrollo durante el Renacimiento, originalmente se refería al contrapunto improvisado, lo que empezó a cambiar con el surgimiento cada vez mayor de la escritura musical; de tal forma que a partir del siglo Xvi empezaron a emerger permutaciones, es decir, composiciones escritas en estilo improvisado y, más aún, prácticas de improvisación moldeadas con propiedades surgidas de la notación musical, ${ }^{14}$ como es el caso de los versos para órgano surgidos en la Península Ibérica. Dicho intercambio se empieza también a reflejar en el surgimiento e incremento de aquellos términos utilizados para distinguir la composición escrita de la improvisación oral. Así, el contrapunto improvisado puede ser también escrito, en cuyo caso es denominado "composición", "canto de órgano" o "canto figurado". En aquella época el vocablo compositio no se refería siempre a la composición escrita, como lo es hoy día, por lo que el musicólogo Rob W. Wegman sugiere ${ }^{15}$ que el concepto "compositor" y la terminología utilizada para describir este oficio surgió precisamente como consecuencia de la contraposición composición-improvisación dentro del ámbito de la música vocal. Un ejemplo que ilustra muy bien este cambio de concepción transversal entre la tradición oral y la escrita lo tenemos en la Declaración de instrumentos musicales del teórico musical y compositor Juan Bermudo, cuando afirma lo siguiente:

I3. Del latín contrapunctus, de contra punctum: "nota contra nota". Dicho término, que encontramos a partir del siglo xIV, se usa para describir la combinación simultánea de líneas de sonidos de acuerdo a un sistema de reglas musicales. También se usa para designar una voz o incluso - como en el caso de los versos para órgano-, composiciones enteras (véase Grove Music Online, www.oxfordmusiconline.com/public/book/omo_gmo).

I4. Rob W. Wegman, "Improvisation, II. Western art music. I. Introduction", en Grove Music Online.

I5. Rob W. Wegman, "From Maker to Composer: Improvisation and Musical Autorship in the Low Countries, I 450-I 500", Journal of the American Musicological Society, 49/3 (I 996): 477. 
hay hombres en ello [refiriéndose a la improvisación del contrapunto] son tan expertos, de tanta cuenta y erudición: que así lo echan a muchas voces y tan acertado, y fugado, que parece composición sobre todo el estudio del mundo. En la extrema capilla del reverendísimo arzobispo de Toledo, Fonseca, de buena memoria vi tan diestros cantores echar contrapunto, que si se apuntara: se vendiera por una buena composición. En la no menos religiosa que doctísima capilla real de Granada, hay tan grandes habilidades en contrapunto: que otros oídos mas delicados que los míos eran menester para comprenderlas y otra pluma para explicarlas [...] De aquí es que algunos no quieran este arte se llame de contrapunto; sino de composición. ${ }^{16}$

Como podemos apreciar, los mecanismos con los que los músicos aprendían e improvisaban polifonía en un principio eran sumamente parecidos a lo que llamamos composición hoy día, además de que tal aprendizaje, utilizado tanto en la música litúrgica como en la polifonía para instrumentos, era uno de los elementos más importantes para la formación de un buen músico. El contrapunto improvisado sobre cantus firmus era una práctica muy difundida a gran escala en cualquier territorio católico, en donde era, por tanto, un requisito imprescindible para poder aspirar al puesto de maestro de capilla. Asimismo, se utilizaba en varios ámbitos y géneros musicales, por lo que existían diversas técnicas de improvisación, como el llamado fauxbourdon o falsobordone ("bajo falso"), cuya secuencia de intervalos, que se mueven por terceras y cuartas paralelas, crea precisamente una especie de fórmula canónica improvisatoria que desde el siglo XVI podemos encontrar plasmada en gran parte de la literatura musical litúrgica y profana: ${ }^{17}$

en los de segunda clase, ha de ser el tercer salmo de esta manera: un verso en el órgano, y otro en fabordón, por las voces y bajos en el facistol: esto ha sido de costumbre y aun prevenido en la cartilla de músicos, mas en el tiempo presente a causa de la escasez de voces que hay en la capilla, juzgo que con acuerdo del señor Chantre y el

I6. Juan Bermudo, Declaración de instrumentos musicales (Osuna, I 55 ); edición facsímil en Documenta Musicologica, XI (Basilea: Bärenreiter, I955), fol. I28r.

I7. Cabe mencionar que el término "fabordón" también se utiliza en un manuscrito de versos para instrumentos del italiano Santiago Billioni (ca. I700-ca. I763) en la catedral de Durango: Drew Edward Davies, Catálogo de música del Archivo Histórico de la Arquidiócesis de Durango (México: Universidad Nacional Autónoma de México-Instituto de Investigaciones Estéticas/Apoyo al Desarrollo de Archivos y Bibliotecas de México, 2013), 232. 
DOI: http://dx.doi.org/10.22201/iie.18703062e.2014.105.2529

LOS VERSOS INSTRUMENTALES DE IGNACIO JERUSALEM

maestro de capilla, se está practicando el cantar este salmo de vísperas en fabordón con las voces bajos y el acompañamiento de órgano. ${ }^{18}$

Esto último, relatado en El costumbrero de la Catedral de México en I 8 I9, indica no sólo que ya para principios del siglo xIx existía una escasez de voces en la capilla de la Catedral de México, sino que además, dichos bajos o cantores preferían aprenderse de memoria una fórmula musical, a leer notación; posicionando el punto de partida de su elección en el medio de la tradición oral y la escrita. ${ }^{\text {I9 }}$

Es posible rastrear en el siglo Xvi los versos para conjuntos de instrumentos transplantados al Nuevo Mundo, tal y como el musicólogo español Javier Marín López lo señala. ${ }^{20}$ Ejemplo clave de dichas tipologías es el MS I9 de la catedral de Puebla, único libro para uso de ministriles hasta ahora encontrado en el Nuevo Mundo. ${ }^{2 I}$ Este documento nos indica que la práctica del alternatim con los instrumentos no sólo se usaba paralelamente y en combinación con la del órgano, sino que además sus estructuras modales y contrapuntísticas en un principio, al igual que los versos para instrumentos peninsulares, ${ }^{22}$ se asemejan a la tradición escrita conservada de los versos para órgano.

Así, las grandes lagunas documentales que existen respecto a estas tipologías, además de plantearnos preguntas respecto a la improvisación de los instrumentos

I8. ассмм, El costumbrero de la Catedral de México I 8 I9 (escrito por el sochantre P. Vicente Gómez), 52-53.

19. Esto, cabe aclarar, podría indicar en este particular caso una menor preparación musical en las voces que formaban la capilla, pues como sabemos que ya desde finales del siglo XviII hechos como la abrogación de la inmunidad eclesiástica del clero, y más tarde, la guerra y el triunfo de la independencia asestaron un duro golpe a la Iglesia mexicana. Esto, si bien no afectó la vida inmediata de las celebraciones litúrgicas en las cuales precisamente espacios como las catedrales e iglesias llegaron a recibir a los ejércitos victoriosos de uno u otro bando, sí fue permeando paulatinamente la vida en el ámbito musical.

20. Javier Marín López, notas al libreto (9-2I) del disco compacto: Ministriles novohispanos. Obras del manuscrito I 9 de la catedral de Puebla de los Ángeles (Las Palmas, Gran Canaria: Sociedad Española de Musicología/Ensamble La Danserye, 20 I2).

2I. Marín, Ministriles novohispanos, I 2. Otros ejemplos aquí citados por Javier Marín López son: un verso para dos chirimías y órgano atribuido a Manuel Blasco, en Bogotá, así como unos versos para bajoncillo, en Cuzco.

22. Respecto a estas tipologías en su contexto peninsular véase Antonio Ezquerro Esteban, Música instrumental en las catedrales españolas en la época ilustrada (conciertos, versos y sonatas, para chirimía, oboe, flauta y bajón con violines y/u órgano de La Seo y El pilar de Zaragoza), Monumentos de la Música Española 69 (Barcelona: Consejo Superior de Investigaciones Científicas-Instituto Español de Musicología, 2004). 
y a la circulación de la música para éstos, nos obligan a trasladarnos más de un siglo adelante para volver a encontrar versos instrumentales en la Nueva España, esta vez bajo la influencia de los nuevos estilos que llegaban de Occidente con compositores como el italiano-mexicano Ignacio Jerusalem y Stella.

\title{
Los versos instrumentales en la Catedral de México: la transformación de una tradición
}

\begin{abstract}
por no haber pieza chica ni grande compuesta por el referido Jerusalem que no fuese de la admiración aún de los mismos inteligentes y la respetaban hasta por un milagro de la música que brillaba en lo muy patético y armónico de toda su composición. ${ }^{23}$
\end{abstract}

Al tomar y dejar su cargo, cada maestro de capilla en la Catedral de México debía realizar un inventario de los libros y papeles sueltos. Tal labor podía llevarla a cabo también el chantre, cuando el cabildo se lo pidiera, debido a que el Archivo musical se enriquecía y ampliaba constantemente. En el siglo XvII, sin embargo, el cabildo de la catedral de México dictó una orden para deshacerse de un buen número de "libros viejos conteniendo juegos de música para distintas festividades", libros que se consideraban inservibles por contener música compuesta en "época ya muy remota". ${ }^{24}$ Esto mismo lo retoma Jerusalem y Stella un siglo después cuando alude a las obras inventariadas por él mismo "a excepción de aquellas cuyos papeles se han destruido, tanto por lo antiguo de su servicio, como también por algunas pérdidas causadas por poco cuidado de los que han tenido la llave del archivo". ${ }^{25}$ Por tanto, la actitud de darle a la música escrita una especie de valor artístico que rebasaba la función utilitaria de la música dentro de la liturgia, y que la hacía merecedora de su conservación, ordenación y catalogación, empieza a surgir de manera paralela —o como reacción— durante el siglo XVI, cuando vemos aparecer, primero, especies de inventarios de los bienes de la Catedral en general y posteriormente, a partir del siglo XviII en adelante, inventarios

23. ассмм, Actas de cabildo, lib. 5i, fol. I8r, 2 I de enero de I77I.

24. Jesús Estrada, Música y músicos de la época virreinal, SepSetentas 95 (México: Secretaría de Educación Pública, I973), 27.

25. АсСмм, A22 I I, fol. Ir. 
DOI: http://dx.doi.org/10.22201/iie.18703062e.2014.105.2529

LOS VERSOS INSTRUMENTALES DE IGNACIO JERUSALEM

ya dedicados exclusivamente al Archivo musical. ${ }^{26}$ A lo largo del tiempo, tales documentos tuvieron como uno de sus objetivos, que el maestro de capilla se comprometiese a dar cuentas, no sólo de la música que se le había encargado en un principio, sino también a dejar en el Archivo la que había compuesto durante su periodo en el puesto.

En 1765 el Cabildo pidió a Ignacio Jerusalem y Stella que elaborase "con la mayor exactitud y prontitud el Archivo de los libros y papeles de la capilla de la música de esta Santa Iglesia haciéndose con la debida separación y claridad". ${ }^{27}$ Sin embargo, cuatro años tuvieron que pasar, en medio de insistencias "por varios modos políticos y extrajudiciales", ${ }^{28}$ para que Jerusalem y Stella se "hallara trabajando en dichos papeles". ${ }^{29}$ Es en la primera página de dicho inventario, ${ }^{30}$ donde, junto con el resto de las composiciones de Jerusalem y Stella, se mencionan por primera vez sus versos para instrumentos o "versos para los Psalmos alternados de el canto llano", ${ }^{\text {I }}$ como los denomina el compositor, de los cuales cabe mencionar que un juego de los ahí citados no se ha conservado actualmente en el Archivo de la Catedral. Respecto a los otros nueve sobrevivientes, seis se preservaron agrupados juntos en cuadernillos o papeles sueltos, ${ }^{32}$ separados por instrumentos y los otros tres se encuentran cada uno de manera independiente.

Efectivamente, Jerusalem y Stella puso de nuevo en circulación dichas tipologías que, más tarde, se propagaron a otras catedrales e iglesias menores de la Nueva España. Sin embargo, debido a que este compositor se convirtió en uno de los principales agentes en introducir y propiciar la circulación de estilos,

26. Para información más detallada respecto a estos inventarios véase: Marín López, "Música y músicos entre dos mundos", 594-65 I.

27. ассмм, Actas de cabildo, lib. 47, fol. 69r, 22 de enero de 1765 .

28. ассмм, Actas de cabildo, lib. 48, fol. 267r, 8 de enero de 1768 .

29. ассмм, Actas de cabildo, lib. 49, fol. 69r, 22 de enero de 1768.

30. El inventario está conformado por cuatro secciones: las dos primeras contienen composiciones de Jerusalem y Stella, mientras que la tercera es un inventario de música que Jerusalem y Stella adquirió para el archivo en I75 I y la cuarta enlista obras compradas por el maestro de infantes, Manuel de Acevedo.

3I. Además del presente artículo, es importante señalar los escritos pioneros respecto a los versos instrumentales del siglo xviII: Karl Bellinghausen, "El verso: primera manifestación orquestal en México", Heterofonía, núm. I07 (1992): 76-85; y Fernando Serrano Arias, "Manuel Delgado. Versos de $5^{\circ}$ tono. Comentarios editoriales", Heterofonía, núm. I 25 (2001): I03-I 23.

32. El término "papeles sueltos" se utiliza en las Actas de cabildo en oposición al de "Libro de facistol", y corresponde a papeles en disposiciones horizontal y vertical, agrupados y separados por instrumentos. 
DOI: http://dx.doi.org/10.22201/iie.18703062e.2014.105.2529

I06

JAZMÍN RINCÓN

formas y géneros ajenos hasta entonces en la música devocional dentro de la Nueva España, la transformación estilística que sufrieron los versos instrumentales saca además a la luz un tema poco tratado en la historiografía de la música catedralicia en México: la transición hacia la adopción de la moderna tonalidad bimodal en detrimento del sistema modal. ${ }^{33}$ Este cambio en la práctica musical se había extendido en Europa a mediados de siglo más allá de las fronteras de la nobleza para convertirse en un lenguaje musical de la burguesía extendido en la cultura occidental.

Seis años antes de entrar a trabajar en la capilla de la Catedral, en I743, Jerusalem y Stella llegó a la Nueva Espańa contratado de antemano por José Cárdenas, administrador del hospital y contador honorario del Real Tribunal de Cuentas para ocupar una plaza titular en el coliseo que más tarde sería el Coliseo Nuevo de México, y en donde se sabe se produjo una gran cantidad de ópera y de música para teatro. Además, antes de I743, Jerusalem y Stella había trabajado componiendo música para teatro en el Coliseo de Cádiz, ciudad espańola, donde la ópera italiana era bien conocida y promovida. ${ }^{34}$ Aunque sabemos poquísimo de esta música, preservada gracias a los archivos catedralicios, el lenguaje de las composiciones surgidas al servicio del ritual dirige la mirada hacia una tradición que formaba parte precisamente de la experiencia y red global, de la cual Jerusalem emergió antes de ingresar a trabajar como maestro de capilla en la Catedral Metropolitana: obras tonales en estilo galante con elementos italianizados ${ }^{35}$ en

33. Cito algunos libros y artículos recientes con relación al tema: Gregory Barnett, "Modal Theory, Church Keys, and the Sonata at the End of the Seventeenth Century", Journal of the American Musicological Society, núm. 5 I/2 (1998): 245-8 I; Gregory Barnett, “Tonal Organization in Seventeenth-century Music Theory", en The Cambridge History of Western Music Theory, ed. Thomas Christensen (Cambridge University Press, 2002), 407-455; Michael R. Dodds, "Tonal Types and Modal Equivalence in Two Keyboard Cycles by Murschhauser", en Tonal Structures in Early Music, ed. Cristle Collins Judd (Nueva York: Garland Publishing, 1998).

34. Antonio Martín Moreno, Historia de la música española, vol. 4, siglo XviII (Madrid: Alianza Editorial, 2006), 373.

35. En la bibliografía concerniente al presente tema en castellano a la que he tenido acceso, el término utilizado es "italianizante", a excepción de los escritos de Drew Edward Davies, quien utiliza la palabra "italianizado". En el presente artículo opté, al igual que Davies, por el participio pasado "italianizado", debido a que se acerca más a la idea aquí expresada de algo que ya ha sido influenciado por lo italiano, a diferencia del adjetivo "italianizante" que se podría entender como algo que ejerce la acción de italianizar (véase Drew Edward Davies, The Italianized Frontier: Music at Durango Cathedral, Español Culture, and the Aesthetics of Devotion in EighteenthCentury New Spain [University of Chicago, 2006], 48-6I; "El sacramento galante: ¿'maravilla rara’ o 'galán amante?", en III Coloquio Musicat. Lo sagrado y lo profano en la festividad de 
DOI: http://dx.doi.org/10.22201/iie.18703062e.2014.105.2529

LOS VERSOS INSTRUMENTALES DE IGNACIO JERUSALEM

las cuales es característico el uso de recursos retóricos y dramáticos de la voz, provenientes del ámbito teatral y enfatizados mediante el canto solista virtuoso; así como motivos melódicos con variedad rítmica en un acompañamiento instrumental, en donde vemos el uso de la modulación como la esencia del sistema tonal. Esta diferencia estilística con la que Jerusalem y Stella había sido tan bien recibido en el Coliseo de México, ${ }^{36}$ provocó en el examen de oposición para el maestrazgo de capilla en la Catedral Metropolitana de 1750 —en el que figuró como único candidato-, unos cuantos tropiezos y choques con la tradición musical que hasta entonces se había dado en la Catedral, como lo podemos leer a continuación:

se le mandó [para calificar las obras de contrapunto y composición ejecutadas por Jerusalem] que, allá a su modo y como pudiese, explicase lo que tenía entendido de la música y con particularidad del canto llano, y se previno al mismo tiempo a los examinadores que si dificultasen sobre alguna cosa de las que dijese se la replicasen y si entendían que erraba en algo se lo enmendasen y corrigiesen. Con efecto, hizo así, y, con voces y palabras mestizas y no bien perceptibles, discurrió, explicó y expuso por un buen rato de tiempo las principales y más sustanciales reglas de la música armónica o canto llano y también algunas de la cromática o canto figurado, ${ }^{37}$ del contrapunto, concierto y composición, diciendo a lo último que así se aprendía y se enseńaba la música en su tierra la Italia y demás naciones extranjeras, y que no se necesitaba de más discursos ni libros antiguos para comprender, enseñar y aprender perfectamente la música que lo que él llevaba dicho y algunas pocas cosas más, por ser la verdadera ciencia de la música sólo la arreglada ejecución de ella.. ${ }^{38}$

Corpus Christi, Seminario Nacional de Música en la Nueva España y el México Independiente (México: Universidad Nacional Autónoma de México-Instituto de Investigaciones Estéticas, 2008), I 45-I67.

36. A su llegada, Jerusalem y Stella fue recibido con gran beneplácito de la aristocracia, la cual declaró que su talento musical "era igual o superior al del maestro de la Capilla Real de Madrid" (cita tomada de: Gabriel Pareyón, "Diccionario Enciclopédico de Música en Mexico”, vol. 2 [Guadalajara, México: Universidad Panamericana, 2007], 537-538).

37. La diferencia que se hace aquí al distinguir canto llano de canto figurado es el uso de compases prefijados — en el caso del canto figurado-, así como la utilización del cromatismo, lo cual veremos más adelante desplazado y reflejado en parte en los versos para instrumentos de Jerusalem.

38. Fernando Zamora y Jesús Alfaro Cruz, "El examen de oposición de Ignacio de Jerusalem y Stella", en Cuadernos del Seminario Nacional de Música en la Nueva España y el México Independiente, núm. I (2007): I6. 
DOI: http://dx.doi.org/10.22201/iie.18703062e.2014.105.2529

I08

JAZMÍN RINCÓN

Como se puede observar a lo largo del expediente con los autos formados para el examen de oposición de maestrazgo de capilla de Ignacio Jerusalem, ${ }^{39}$ para obtener tal cargo, se examinaba a los postulantes en el conocimiento de las fórmulas cantadas en la misa y el oficio, para lo cual era necesario saberse tales fórmulas usuales, es decir; entonar el himno de tercia, las antífonas de la virgen, los versículos de invocación del oficio, los responsorios breves de las horas menores, entre otros, por lo que todos éstos resultaban elementos básicos y necesarios para las funciones prácticas de un maestro de capilla. Sabemos también que cualquier músico, por más lejano de la Iglesia que estuviera en aquella época, tenía experiencia práctica en el ámbito litúrgico de la música, es decir, conocía el orden de la participación de la música en el rito de la misa y el oficio. ${ }^{40}$

Aunque resulta notoria, tanto la reticencia de las autoridades eclesiásticas respecto a la escuela y tradición a la que pertenecía Jerusalem y Stella "por no tener costumbre de catedral", ${ }^{\mathrm{I}}$ como los numerosos tropiezos y choques que se dieron cuando se le pedía algo y lo hacía "según su modo de entender, no como debe ser”; ${ }^{2}$ llama también la atención cómo a pesar de las diferencias, el dictamen reconoce positivamente la preparación del italiano; su habilidad en la composición, y un especial reconocimiento en lo que se refiere al acompańamiento de los instrumentos:

39. El documento consta de las siguientes partes: I. portada (fol. 98); 2. edicto convocatorio (fol. 99); 3. informe de Luis Fernando de Hoyos Mier y Francisco Ximénez Caso (fols. IooI03); 4. dictamen de Miguel de Herrera (fol. I04); 5. dictamen de Joseph González (fol. I05); 6. dictamen de Martín Vázquez de Mendoza (fol. I06); 7. dictamen de Miguel Gallegos (fol. I07-I07v); 8. villancico $A$ la milagrosa escuela (fol. ro8); 9. cuenta de la música que se copió (fol. I09); Iо. acuerdo de aceptación (fol. I Io); I I. Antífona O Emmanuel Rex (fol. I I I-I I Iv); I 2. dictamen de Juan Joseph Durán y León (fol. I I 2); I 3. contrapunto de tema (O Emmanuel Rex; fols. I I4-II6v); I4. hoja pautada con notación musical (fol. I I7v); I 5. Antífona Iste Sanctus, fragmento (fol. II8-II8v); I6. fuga a cuatro voces (fol. II9-II9v); I7. bajo de contrapunto (fol. I20); I 8. parte de bajo (O Emmanuel Rex; fols. I20v-I2Iv); I9. parte de contralto (O Emmanuel Rex; fols. I22-I 23); 20. parte de tenor (O Emmanuel Rex; fols. I 24I 25); 2 I. parte de tiple (O Emmanuel Rex; fols. I26-I 27); 22. parte de contralto (Iste Sanctus; fol. I 3 IV); y 24. parte de tenor (Iste Sanctus; fol. I32v). Información tomada de: Zamora y Alfaro Cruz, "El examen de oposición de Ignacio de Jerusalem y Stella", I 2-I 3.

40. Estamos hablando de una época en la que la educación no era laica, por lo que el estudio de la teología y la retórica eran parte de la educación básica en los países católicos como Italia y España.

4I. Zamora y Alfaro Cruz, "El examen de oposición de Ignacio de Jerusalem y Stella", I7.

42. Zamora y Alfaro Cruz, "El examen de oposición de Ignacio de Jerusalem y Stella", I7. 
DOI: http://dx.doi.org/10.22201/iie.18703062e.2014.105.2529

LOS VERSOS INSTRUMENTALES DE IGNACIO JERUSALEM

Por lo que toca a la práctica y ejecución de lo que es música —y [que] debe poseer principalmente el que habría de obtener el magisterio de capilla-, es también cierto que, así como vimos que tropezaba [Jerusalem] y escaseaba en la explicación y en las voces, vimos también que, con notable agilidad y expedición, se desembarazaba y respondía a lo que se le preguntaba con la pluma en la mano, haciendo y formando de repente sobre el papel rayado, con figuras y notas, lo que se le mandaba que hiciese, conviniendo los examinadores en que estaba con arreglamento lo compuesto, de que alguno o algunos fragmentos se hallan en los autos. Así el contrapunto como el villancico a cuatro, compuesto uno y otro en el preciso término de veinte y cuatro horas que se le asignó para cada uno - ya vuestra señoría ilustrísima los oyó cantar públicamente en el coro-, con la especialidad que compuso también dentro [de] el mismo tiempo las voces del acompańamiento de instrumentos, sin ser esto de la obligación de los que se examinan, sino tan sólo el meter las voces y no los instrumentos. ${ }^{43}$

En efecto, a pesar de que anteriormente Manuel de Sumaya (I 678-I755) había encabezado el uso de violines en sus obras, la escritura de Jerusalem y Stella en lo que concierne a los instrumentos en general, y a los violines en particular, adquiere un gran protagonismo e independencia técnica en sus composiciones vocales. Así, a diferencia de las obras con violines de Sumaya, por primera vez nos encontramos con una escritura idiomática para instrumentos en la Catedral, de tal forma que las posibilidades de cada instrumento — en especial, los violines_ 44 se exploran más allá de la línea melódica que pueden producir, al protagonizar y comentar pasajes por medio de ritmos diversos o cuerdas dobles, cromatismos u otros efectos al servicio del texto. Esta utilización de los instrumentos desencadenó composiciones instrumentales, por lo que a partir de Jerusalem encontramos en los archivos catedralicios manuscritos con escritura idiomática para conjuntos de instrumentos pertenecientes a un compositor local, como es el caso de las oberturas en tres movimientos localizadas en el Archivo de la Catedral de Durango, ${ }^{45}$ y los versos para instrumentos.

43. Zamora y Alfaro Cruz, "El examen de oposición de Ignacio de Jerusalem y Stella", i6. 44. Cabe destacar que al igual que en las catedrales españolas, el violín se introduce en Hispanoamérica en el siglo XviII precisamente por los italianos: encontramos en la Catedral Metropolitana a destacados violinistas provenientes de Italia, tales como José Givomo Laneri, Francisco Todini y Gregorio Panseco, entre otros. Además, parte de los violines con los que contaba la capilla de música de la catedral provenían de constructores napolitanos.

45. Davies, The Italianized Frontier, 258-264. 
Los nueve juegos de versos que se encuentran actualmente en el Archivo están agrupados juntos en cuadernillos o papeles sueltos separados por instrumentos (A059r.01, A0591.02, A0591.03, A059r.04, Ao591. o 5 y A0591.06) y los otros tres se encuentran cada uno de manera independiente (A0590, A0 592, Ao593), aunque también separados por instrumentos, pues cada ministril contaba con su propio atril.

En el inventario elaborado por Tollis de la Roca en $1770,{ }^{46}$ un año después del fallecimiento de Ignacio Jerusalem y Stella, se incorporaron las composiciones del inventario anterior y además se dividieron en secciones donde se enlistan más detalladamente los mismos diez juegos de versos, y se indica en el décimo que "nueve no están en el Archivo, ni los borradores" debido a que "los tienen los primeros violines". ${ }^{47}$ Esto último, sin embargo, no significa que los que nos han llegado son los otros nueve juegos que Tollis de la Roca menciona, pues aspectos tales como la instrumentación no coinciden completamente con los que se conservan, lo que me lleva a plantear los siguientes argumentos al respecto: a) la instrumentación cambió por razones prácticas, como es el caso de los juegos A0591.03, A0591.04, A0 591. 05 y A0591.06 a los cuales se les añadió posteriormente la parte de las trompas; b) el hecho de que encontremos varios de estos juegos de versos en archivos como el de la Basílica de Guadalupe o en Durango y Puebla, entre otras ciudades, indica que la circulación de los versos de Jerusalem, así como su uso práctico dentro del ritual, provocó su desgaste y reproducción, por lo que; c) la caligrafía de los versos pertenece a copistas posteriores a la muerte de Jerusalem.

Aunque no haya ninguna presencia temática evidente de las fórmulas salmódicas del canto llano en los versos para instrumentos de Jerusalem, queda claro, por la condición que tenían los compositores de su época — capaces de moverse con comodidad y éxito del ámbito extraeclesial al ámbito catedralicio-, que dichas fórmulas estuvieron en la mente del compositor en el caso de los versos para instrumentos. El simple hecho de que el inventario de Jerusalem y Stella los denomine "versos para los Psalmos alternados" y más tarde el de Tollis de la Rocca añada que son de "tercia, vísperas y maitines", habla además de un conocimiento práctico que incluye elementos como las fórmulas salmódicas y el contexto ritual. De tal forma que al confrontar algunas de las mencionadas fórmulas cantadas con los versos para instrumentos, se puede comprobar la coherencia

46. ассмм, A22 I 2: "Testimonio de el imbentario de musica que esta a mi cargo".

47. Ассмм, A22 I 2: "Testimonio de el imbentario de musica que esta a mi cargo", I 2. 
DOI: http://dx.doi.org/10.22201/iie.18703062e.2014.105.2529

LOS VERSOS INSTRUMENTALES DE IGNACIO JERUSALEM

tonal y modal que existe entre ambos, lo que significa muy probablemente que estos juegos de versos — al igual que sus predecesores — no estaban asignados a un salmo o himno en específico, sino que, siempre y cuando se respetara la coherencia entre tono y modo, podían adaptarse y usarse con varios de ellos. Así, compositores como Jerusalem y Stella estaban obligados a discernir las relaciones entre modalidad y tonalidad, lo que resulta bastante claro en tipologías como los versos para instrumentos, donde las tonalidades están definidas con base en el sistema modal del canto gregoriano o canto llano..$^{8}$

A pesar de que no es posible saber con certeza cuál fue el primer juego de versos que Jerusalem y Stella compuso, se pueden observar en los manuscritos elementos transicionales y experimentales, que dan indicios de una cronología, lo cual me ha llevado a dividir las obras en dos grupos:

I. Los juegos A0591.01, A0592.02, A0 592.03, A0592.04, A0592.05, y Ao592.06 (véase la fig. 3), agrupados en cuadernillos por instrumentos, presen$\tan$ los siguientes aspectos que permiten deducir que fueron los primeros versos instrumentales compuestos por Ignacio Jerusalem y Stella: a) son los versos más breves de toda la colección que hay en la Catedral de México; b) presentan una cadencia o pausa intermedia, muchas de las veces indicada con doble línea en la notación y un calderón en su resolución, por lo que su estructura corresponde a la de las fórmulas salmódicas divididas en dos hemistiquios; c) son los únicos juegos de versos que están numerados, es decir, que no contienen indicación de tempo (Allegro, Adagio, entre otros), emparentándose directamente con los versos para órgano y los versos para conjuntos de instrumentos que se han conservado, tales como los del Ms ig de la catedral de Puebla; d) la instrumentación, pensada inicialmente para dos violines y bajo, es la más sencilla de los nueve juegos, pues las trompas, utilizadas igualmente por Jerusalem y Stella en obras vocales posteriores, se añadieron después, ya sea doblando los violines en el A0592.02 o separadamente en los juegos A0592.03, A0592.04, A0592.05, y A0592.06, además, el registro que abarcan los violines es estrecho en comparación con los juegos posteriores, lo cual podría indicar su adecuación a las fórmulas cantadas.

2. Los otros tres juegos de versos, A0 590, A0592, A0593 (véase la fig. 7), más variados entre sí respecto a la instrumentación y que muy probablemente

48. Esto es fundamental en la interpretación, pues el hecho de que la notación de los versos no incluya ninguna referencia directa a la correspondiente música litúrgica no quiere decir que no esté íntimamente ligada a ella, por lo cual puede resultar uno de los principales problemas para el estudio y ejecución de la música que surgió y estaba al servicio de la liturgia catedralicia y conventual. 


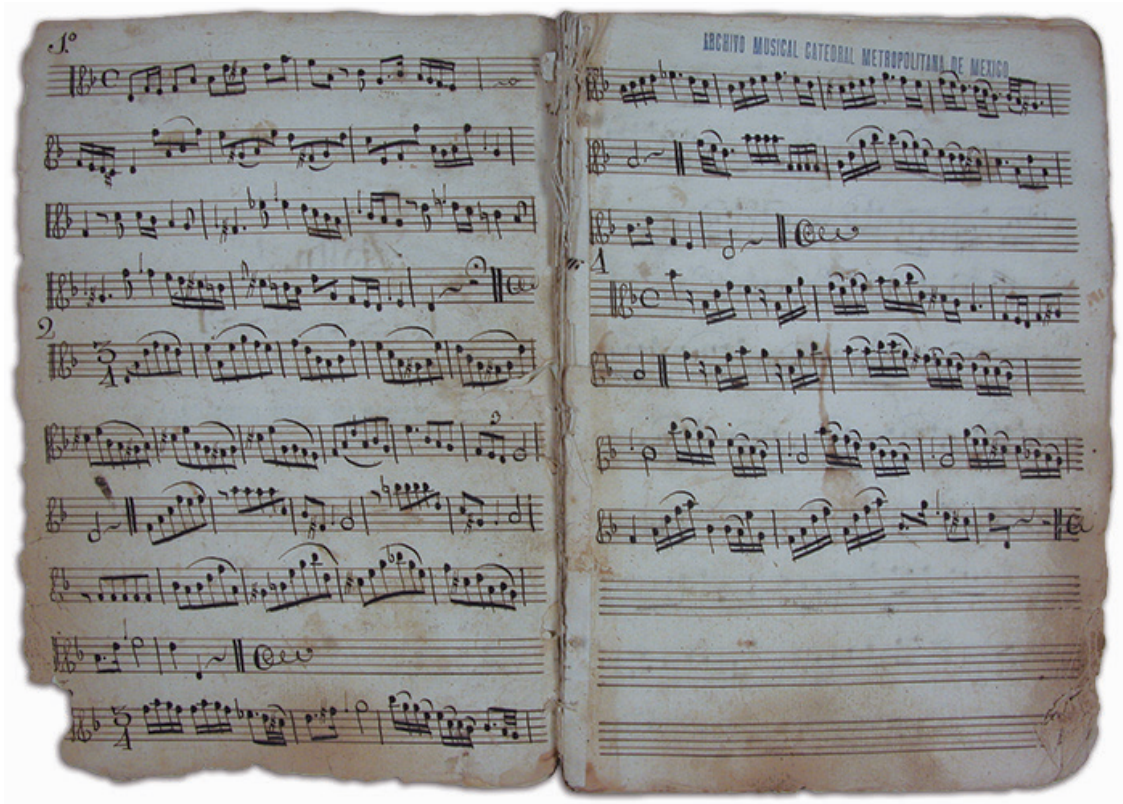

3. Primeros dos folios de la parte del violín primero del juego de versos, Archivo del Cabildo Catedral Metropolitano de México, Ao59i.o i. Conaculta-InAH-MÉx. "Reproducción autorizada por el Instituto Nacional de Antropología e Historia."

se escribieron con posteridad, presentan las siguientes características: a) tienen una duración más larga; b) contienen indicación de tempo (Adagio, Allegro, entre otros); c) los juegos A0590 y A0592 no muestran una pausa o cadencia intermedia que corresponda a la división por hemistiquios; d) el juego A0593 (fig. 4) sí muestra divisiones en algunos de sus versos, como en los dos allegrettos; sin embargo, éstas están indicadas con doble punto o repetición, tanto en la cadencia intermedia como al final, lo que les daría la forma binaria AABB, acercándolos más a la forma sonata que a las fórmulas salmódicas; c) el lenguaje musical que presentan los tres juegos, con recapitulaciones y partes de solos en las secciones de instrumentos, los vuelve más independientes de una estructura basada en los salmos, a diferencia de los anteriores seis juegos; d) la instrumentación refleja, además de un diálogo basado en los diferentes timbres y agrupaciones de los instrumentos, un hecho práctico relacionado con los mismos instrumentos que se iban adquiriendo y usando en la capilla musical de la Catedral de México alrededor del siglo xviII; tal es el caso de la introducción de los violines y las 


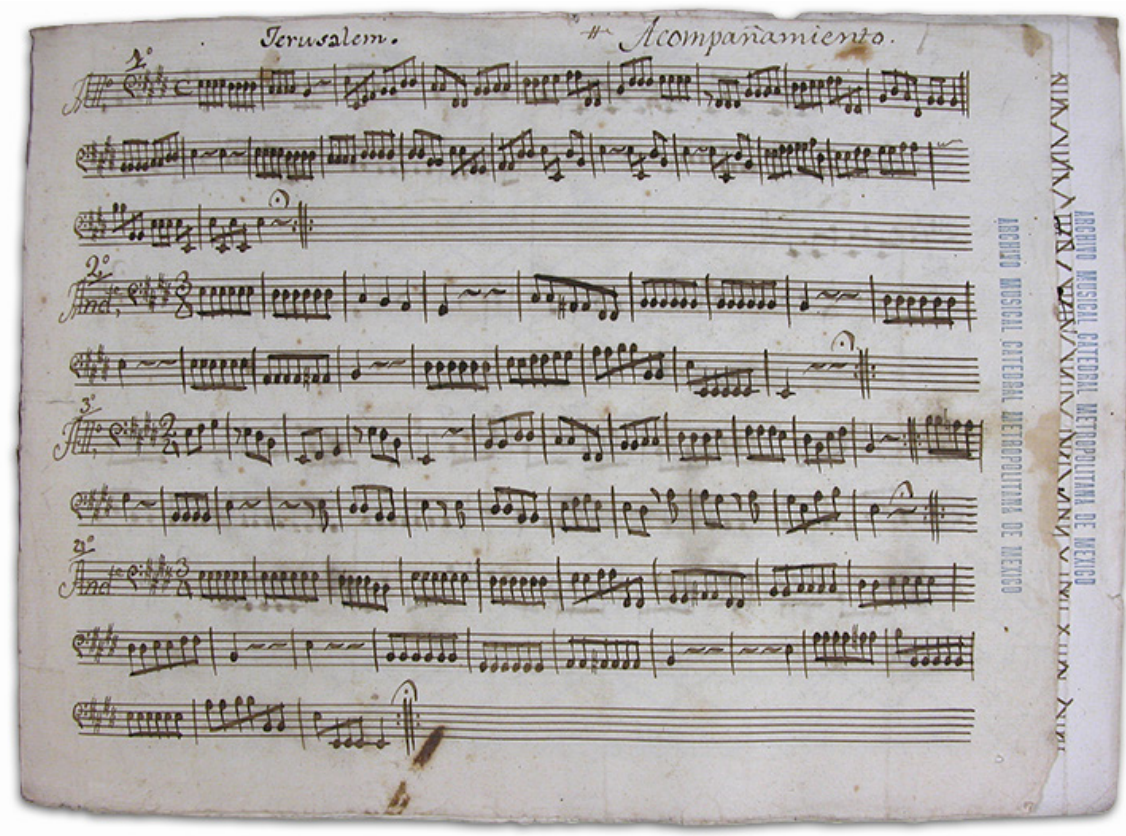

4. Primer folio de la parte del acompañamiento del juego de versos, Archivo del Cabildo Catedral Metropolitano de México, Ao593. Conaculta-InAH-MÉx. "Reproducción autorizada por el Instituto Nacional de Antropología e Historia."

trompas primeramente, y después, de instrumentos como los clarines (I753), 49 el fagot (I760) ${ }^{50}$ y los timbales (I756); ${ }^{5 \mathrm{I}}$ lo que nos obliga a datar al menos los juegos A0590 y A0592 como posteriores a I760 (fig. 5).

En las figuras 5 y 6 presento información estructurada que proporcionan los manuscritos, incluyendo el modo correspondiente ${ }^{52}$ de cada uno de los juegos. Los tres elementos en los que me he basado para identificar el modo y de ahí hacer la equivalencia tonal son: a) la nota final o el último acorde; b) el ámbito

49. Marín López, "Música y músicos entre dos mundos", vol. I, 2 I 5.

50. Marín López, "Música y músicos entre dos mundos”, vol. I, 209-2 I 2.

51. Marín López, "Música y músicos entre dos mundos", vol. I, 222-225.

52. Al decir "modo correspondiente" me refiero a la opción que hicieron los compositores para equiparar los tonos con los modos, utilizando las mismas bases teóricas de los modos. Así, en los versos, esto se ve reflejado y se puede encontrar en las tonalidades que escogen para terminar en las mismas notas finales de las fórmulas salmódicas. 
DOI: http://dx.doi.org/10.22201/iie.18703062e.2014.105.2529

I I 4

JAZMÍN RINCÓN

sonoro, es decir, que todas las melodías se desarrollen en la octava normal a partir de la nota final; y por último, c) la dominante del modo, la cual depende de si es auténtico o si es plagal.

Al estar condicionados por la duración tan corta de los versos de los salmos, es notorio cómo los versos instrumentales no permiten un desarrollo muy amplio en el discurso musical. Los primeros seis versos, escritos para dos violines y bajo (y posteriormente dos trompas), tienen una textura homorrítmica y homofónica en la melodía que sustenta el bajo, muchas veces, incluso, yendo el primer y segundo violines en unísono. Éstos y los posteriores juegos están llenos de pequeñas melodías sobre soportes armónicos, partimenti típicos del estilo galante que se repiten continuamente en intervalos o acompañando instrumentos distintos, modulando de manera constante, o también como recapitulaciones en el caso de los versos con cadencias intermedias. También podemos oír ritmos lombardos en todos los juegos, así como apariciones notorias de ritmos diversos y contrastantes en los juegos con mayor instrumentación. Al haber solos de los instrumentos de viento-madera (fagotes) o metal (trompas, clarines), los violines acompañan los solos con acordes como gestos, sumándose así a la improvisación armónica del bajo continuo con el órgano. Así, los elementos encontrados en los versos mencionados de Jerusalem y Stella pertenecen al estilo galante italianizado, cuya relación con el teatro, la música de la alta burguesía europea y el bel canto reflejan el ambiente del cual surgió el compositor italiano.

Al estar al servicio del ritual, los versos respondían a la práctica de las celebraciones litúrgicas, lo cual explica el fenómeno de que los manuscritos hayan circulado tan exitosamente por diversas catedrales e iglesias menores, así como que se hayan ańadido o quitado con posterioridad partes de instrumentos que la Catedral iba adquiriendo o que otras iglesias no tenían. ${ }^{53}$

53. Para encontrar dichas tipologías a partir del siglo xviII, véase: Thomas E. Stanford, $C a-$ tálogo de los acervos musicales de las catedrales metropolitanas de México y Puebla de la Biblioteca Nacional de Antropología e Historia y otras colecciones menores (México: Instituto Nacional de Antropología e Historia, 2002); Aurelio Tello, Archivo de Música del Venerable Cabildo de la catedral de Puebla; Catálogo y Apéndice biográfico (Puebla: Consejo Nacional para la Cultura y las Artes-Instituto Nacional de Bellas Artes-CECAP, 2014) (en prensa); Drew Edward Davies, Catálogo de música del Archivo Histórico de la Arquidiócesis de Durango; John Lazos, Catálogo musical del Archivo Histórico Diocesano de la catedral de San Cristóbal de Las Casas, Chiapasl Music Catalogue of the Historical Diocesan Archives at the Cathedral of San Cristóbal de Las Casas, Chiapas, Series A/II, Musical Manuscripts after I 600 (Répertoire International des Sources Musicales [20 1 2]); Lidia Guerberof Hahn, Archivo Musical/Catálogo, Insigne y Nacional Basílica de Santa María de Guadalupe (México: 2006); Patricia Sanabria Varga y John Lazos, Catálogo 


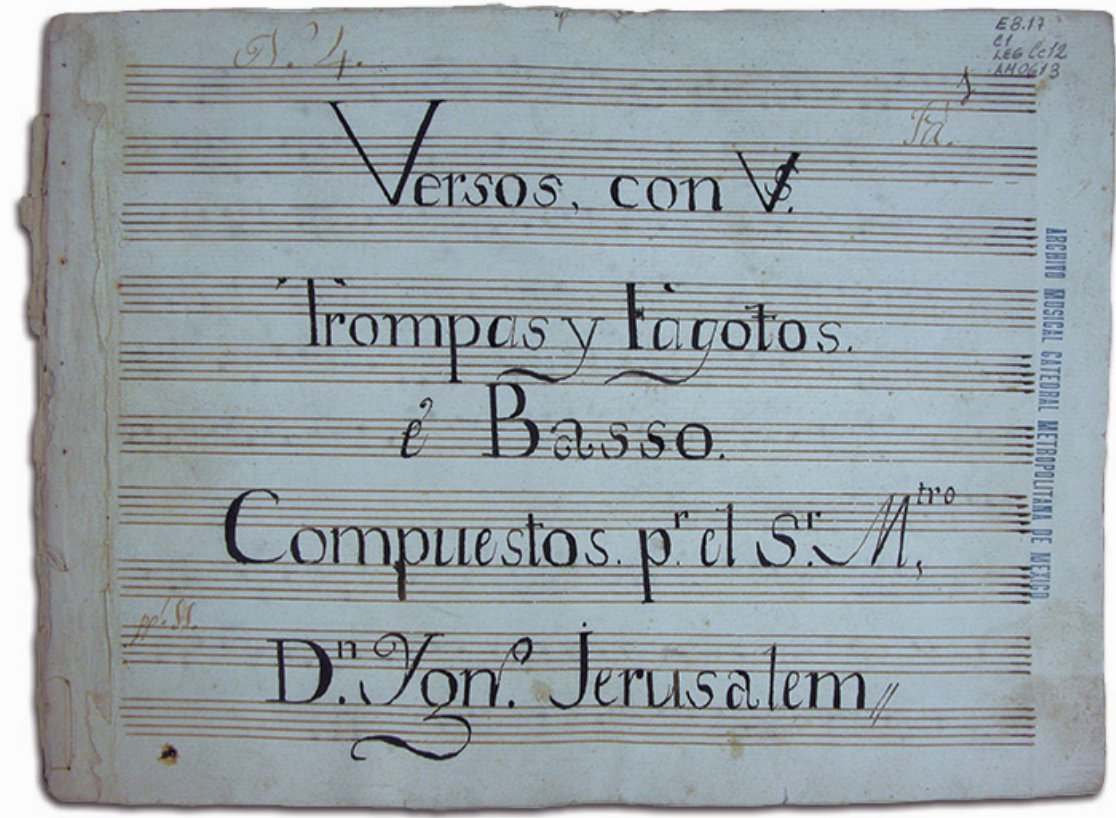

5. Portada del juego de versos, Archivo del Cabildo Catedral Metropolitano de México, A0590. Conaculta-INAH-MÉx. "Reproducción autorizada por el Instituto Nacional de Antropología e Hisotria."

Los manuscritos de versos para instrumentos conservados en la Catedral de México especifican las horas canónicas para las que se compusieron: maitines, tercia y vísperas, así como también laudes, sexta y nona raramente. Además, el inventario de 1770, escrito I9 años después, indica que dichos versos son para "los salmos de tercia, vísperas y maitines". ${ }^{44}$ Sin embargo, en el DIARIO MANUAL 55

del Archivo Histórico Musical de la parroquia El Sagrario de la Catedral de Tulancingo (México: Apoyo al Desarrollo de Archivos y Bibliotecas de México, 2013); y por último: John Lazos, Catálogos de los acervos musicales de las parroquias de Santiago Chazumba y de San Cristóbal de Suchixtlahuaca, en la Sierra Mixteca de Oaxaca (México: Répertoire International des Sources Musicales-Musical Sources in MEX-SCHAMP, 2013).

54. Inventario de I770, redactado por Tollis de la Roca, АССмM, A22 I 2.

55. el diario manval de lo QVe en / Esta Santa Yglesia Cathe / dràl Metropolitana de México se / Practica y Observa, en su Altar, Choro, / y demás que le ès debido hacer en to = / dos, y cada uno de los días del Año. I Arreglado en todo à su Ereccion, / Estatutos, Cartilla, Constumbres, Fun- I daciones y Rubricas. Para su màs= / Puntual ê imbiolable Ôbserv.a / Hecho= / Por el M. Yll.e y 


\title{
I I 6
}

\author{
JAZMÍN RINCÓN
}

Los presentes seis juegos de versos (A0591.01, A0591.02, A0591.03, A0591.04, A0591.05, y Ao59r.06) concuerdan con el Archivo Histórico de la Arquidiócesis de Durango, Ms. Mús. (.or) 264/I, (.02) 264/2, (.03) 296/2, (.04) 296/3, (.06)196/I.

\begin{tabular}{|c|c|c|c|c|c|c|}
\hline Signatura: & A0591.0I & A0591.02 & A0591.03 & A0591.04 & A0591.05 & A0591.06 \\
\hline $\begin{array}{l}\text { Partes } \\
\text { conservadas: }\end{array}$ & \multicolumn{6}{|c|}{$\begin{array}{l}\text { Bajo, } 2 \text { violines primeros, } 2 \text { violines segundos. } \\
\text { Los juegos de versos } .03, .04, .05 \text { y } .06 \text { tienen partes para } 2 \text { trompas que se } \\
\text { ańadieron posteriormente. }\end{array}$} \\
\hline Tonalidad: & Re menor & Sol menor & Sol mayor & Re mayor & Re mayor & Fa mayor \\
\hline $\begin{array}{l}\text { Posible } \\
\text { correlación } \\
\text { de los } \\
\text { modos: }\end{array}$ & $\begin{array}{l}\text { Primero: } \\
\text { D la sol re }\end{array}$ & $\begin{array}{l}\text { Primero o } \\
\text { segundo } \\
\text { transportado: } \\
\text { D la sol re }\end{array}$ & $\begin{array}{l}\text { Séptimo: } \\
\text { G sol re ut }\end{array}$ & $\begin{array}{l}\text { Quinto } \\
\text { transportado: } \\
\text { F fa ut }\end{array}$ & $\begin{array}{l}\text { Quinto } \\
\text { transportado: } \\
\text { F fa ut }\end{array}$ & $\begin{array}{l}\text { Sexto: } \\
\text { F fa ut }\end{array}$ \\
\hline \multirow{2}{*}{$\begin{array}{l}\text { Numeración } \\
\text { de los versos } \\
\text { y número de } \\
\text { compases: }\end{array}$} & $\begin{array}{l}\text { I: } \\
\text { I I }^{*}\end{array}$ & \begin{tabular}{|l} 
I: \\
25
\end{tabular} & $\begin{array}{l}\text { I: } \\
\text { IO }\end{array}$ & $\begin{array}{l}\text { I: } \\
\text { I } 2^{*}\end{array}$ & $\begin{array}{l}\text { I: } \\
\text { I3 }\end{array}$ & $\begin{array}{l}\text { I: } \\
\text { I I }\end{array}$ \\
\hline & $\begin{array}{l}2: \\
24\end{array}$ & \begin{tabular}{|l}
$2:$ \\
I I $^{*}$
\end{tabular} & $\begin{array}{l}\text { 2: } \\
\mathrm{I} 6^{*}\end{array}$ & $\begin{array}{l}\text { 2: } \\
\text { I } 8^{*}\end{array}$ & $\begin{array}{l}\text { 2: } \\
\text { 2I }\end{array}$ & $\begin{array}{l}\text { 2: } \\
\text { I9 }\end{array}$ \\
\hline \multirow{6}{*}{$\begin{array}{l}\left({ }^{*}\right) \text { Indica que } \\
\text { no incluye } \\
\text { hemistiquio } \\
\text { en la } \\
\text { notación. }\end{array}$} & $\begin{array}{l}\text { 3: } \\
\mathrm{I} 3\end{array}$ & \begin{tabular}{|l}
$3:$ \\
$20^{*}$
\end{tabular} & $\begin{array}{l}3: \\
28\end{array}$ & $\begin{array}{l}3: \\
\mathrm{I} 2^{*}\end{array}$ & $\begin{array}{l}3: \\
23\end{array}$ & \begin{tabular}{|l}
$3:$ \\
26 \\
\end{tabular} \\
\hline & $\begin{array}{l}4: \\
\text { I I }\end{array}$ & \begin{tabular}{|l}
$4:$ \\
$20^{*}$
\end{tabular} & $\begin{array}{l}4: \\
25\end{array}$ & $\begin{array}{l}4: \\
26^{*}\end{array}$ & $\begin{array}{l}\text { 4: } \\
29\end{array}$ & $\begin{array}{l}\text { 4: } \\
\mathrm{I} 3 \\
\end{array}$ \\
\hline & $\begin{array}{l}5: \\
18 \\
\end{array}$ & \begin{tabular}{|l:}
$5:$ \\
$20^{*}$ \\
\end{tabular} & $\begin{array}{l}5: \\
16 \\
\end{array}$ & $\begin{array}{l}5: \\
19^{*}\end{array}$ & $\begin{array}{l}5: \\
27\end{array}$ & $\begin{array}{l}5: \\
\text { 2I }\end{array}$ \\
\hline & $\begin{array}{l}\text { 6: } \\
15^{*}\end{array}$ & $\begin{array}{l}\text { 6: } \\
25^{*}\end{array}$ & $\begin{array}{l}\text { 6: } \\
25^{*}\end{array}$ & $\begin{array}{l}\text { 6: } \\
\text { I0* }\end{array}$ & \begin{tabular}{|l}
$6:$ \\
$2 \mathrm{I}^{*}$
\end{tabular} & $\begin{array}{l}\text { 6: } \\
\text { I I }\end{array}$ \\
\hline & \begin{tabular}{|l:}
$7:$ \\
26 \\
\end{tabular} & $\begin{array}{l}7: \\
26^{*}\end{array}$ & \begin{tabular}{|l:} 
7: \\
$\mathrm{I} 7$ \\
\end{tabular} & & \begin{tabular}{|l:}
$7:$ \\
20 \\
\end{tabular} & \\
\hline & & \begin{tabular}{|l:}
$8:$ \\
$25^{*}$
\end{tabular} & & & & \\
\hline Folios: & \multicolumn{6}{|l|}{67} \\
\hline Imágenes: & \multicolumn{6}{|l|}{60} \\
\hline Notas: & \multicolumn{6}{|c|}{$\begin{array}{l}\text { Además de que los juegos de versos } .03, .04, .05 \text { y .06 tienen partes para } \\
2 \text { trompas, las partes de los violines segundos en los seis juegos tienen la } \\
\text { indicación trompa en algunos fragmentos, las cuales no coinciden con las partes } \\
\text { independientes de las trompas. }\end{array}$} \\
\hline
\end{tabular}

6. Los primeros versos instrumentales en la Catedral de México, compuestos entre 1750 y 1760 por Ignacio Jerusalem y Stella (I707-I769). 
DOI: http://dx.doi.org/10.22201/iie.18703062e.2014.105.2529

LOS VERSOS INSTRUMENTALES DE IGNACIO JERUSALEM

\begin{tabular}{|c|c|c|c|}
\hline Signatura: & Ao 590 & $\operatorname{Aos} 92^{I}$ & A0593 \\
\hline $\begin{array}{l}\text { Título del } \\
\text { manuscrito: }\end{array}$ & $\begin{array}{l}\text { Versos, con Vs. / } \\
\text { Trompas y Fagotos. / e } \\
\text { Basso. / Compuestos pr. } \\
\text { el Sr. Mtro. / Dn. Ygn. } \\
\text { Jerusalem. }\end{array}$ & $\begin{array}{l}\text { Acompato. Continuo } \\
\text { de los Bexsos / con Vs. } \\
\text { Trmpas y Fagotos e I } \\
\text { Basso / Por el Sr. Mtro. } \\
\text { Dn. Ygnacio Jerusalem } \\
\text { y Estella }\end{array}$ & $\begin{array}{l}\text { Versos para Tercia } \\
\text { / De el Mtro. D. } \\
\text { Ygnacio Jerusalem }\end{array}$ \\
\hline Tonalidad: & Fa mayor & Mi b mayor & Mi mayor \\
\hline $\begin{array}{l}\text { Posible correlación } \\
\text { de los modos: }\end{array}$ & $\begin{array}{l}\text { Modo quinto o modo } \\
\text { sexto: } \\
\text { F fa ut }\end{array}$ & $\begin{array}{l}\text { Correspondería a } \\
\text { un quinto modo } \\
\text { transportado: } \\
\mathrm{F} \text { fa } \mathrm{ut}^{2}\end{array}$ & $\begin{array}{l}\text { Modo tercero o } \\
\text { séptimo: } \\
\text { G sol re ut }\end{array}$ \\
\hline $\begin{array}{l}\text { Partes } \\
\text { conservadas: }\end{array}$ & $\begin{array}{l}\text { Bajo, } 2 \text { violines, } 2 \\
\text { fagotes, } 2 \text { trompas }\end{array}$ & $\begin{array}{l}\text { Acomp., Bajo, violín } \\
\text { I y 2, fagot I y 2, } \\
\text { Clarín I y 2, Trompa } \\
\text { I y 2, Timbales. }\end{array}$ & $\begin{array}{l}\text { Violín I y } 2, \\
\text { trompa I y } 2 \text {, } \\
\text { Acompañamiento }\end{array}$ \\
\hline $\begin{array}{l}\text { Movimientos } \\
\text { con número de } \\
\text { compases (entre } \\
\text { paréntesis): }\end{array}$ & $\begin{array}{l}\text { I. Allegretto (2 Ic.) } \\
\text { 2. Andante (37c.) } \\
\text { 3. Allegro (42c.) } \\
\text { 4. Andante (48c.) } \\
\text { 5. Allegro (22c.) } \\
\text { 6. Allegro lento (36c.) }\end{array}$ & $\begin{array}{l}\text { I. Andante (20c.) } \\
\text { 2. Andante (I } 8 \mathrm{c} .) \\
\text { 3. Largo (I } 3 \mathrm{C} .) \\
\text { 4. Allegretto (34c.) } \\
\text { 5. Andante (34c.) } \\
\text { 6. Allegro (29c.) }\end{array}$ & $\begin{array}{l}\text { I. Allegro (2 I c.) } \\
\text { 2. Andante (I 8c.) } \\
\text { 3. Allegretto (25c.) } \\
\text { 4. Andante (22c.) } \\
\text { 5. Allegretto (I 5c.) } \\
\text { 6. Andantino } \\
\text { (I I c.) } \\
\text { 7. Allegro (I7c.) }\end{array}$ \\
\hline Folios: & 38 & 56 & 34 \\
\hline Imágenes: & 33 & 47 & $2 \mathrm{I}$ \\
\hline Notas: & $\begin{array}{l}\text { Existen tres partes del } \\
\text { bajo, una de las cuales } \\
\text { está incompleta. } \\
\text { Sólo hay una parte } \\
\text { para el violín I y } \\
\text { dos para el violín } 2 .\end{array}$ & $\begin{array}{l}3 \text { partes para el bajo. } \\
\text { No todos los versos } \\
\text { indican el tempo. } \\
\text { Los clarines están } \\
\text { omitidos en la portada } \\
\text { o título de los versos. } \\
\text { Las partes del clarín I } \\
\text { y } 2 \text { están duplicadas. }\end{array}$ & $\begin{array}{l}\text { Incluyen } \\
\text { repeticiones } \\
\text { indicadas con } \\
\text { doble punto en } \\
\text { la parte del bajo, } \\
\text { además de que los } \\
\text { movimientos } 3 \text { y } \\
5 \text { tienen cadencias } \\
\text { con repeticiones a } \\
\text { la mitad del verso, } \\
\text { en forma AABB. }\end{array}$ \\
\hline & \multicolumn{3}{|c|}{$\begin{array}{l}\text { Ninguno de estos tres juegos de versos contienen hemistiquios en } \\
\text { la notación. }\end{array}$} \\
\hline \multicolumn{4}{|c|}{$\begin{array}{l}\text { I Concuerda con el Archivo Histórico de la Arquidiócesis de Durango, ms. Mús. } 249 \text { (Davies, } \\
\text { Catálogo de versos). } \\
2 \text { Éste es un ejemplo de la falta de correspondencia con los versos que Tollis de la Roca enumera: } \\
\text { a pesar de que este verso coincide completamente con la instrumentación que indica el inventario de } \\
\text { I770 (ACCMM, A22I2), Tollis de la Roca escribe D La Sol Re, lo que no equivale a la tonalidad ni a } \\
\text { la modalidad de este verso. }\end{array}$} \\
\hline
\end{tabular}

7. Juegos de versos instrumentales en al Catedral de México, compuestos entre 1750 y 1760 por Ignacio Jerusalem y Stella (I707-I769). 


\section{I 8}

JAZMÍN RINCÓN

se menciona que se alternan también con himnos y con el Magnificat, al igual que los versos organísticos. Todo esto muestra que existía una variedad, así como adaptabilidad en el uso del alternatim, la cual, cambiaba dependiendo de la importancia de la fiesta celebrada o de aspectos prácticos (figs. 8, 9 y Io).

Este nuevo estilo en la tradición escrita de la música reflejado en las transformaciones de los versos instrumentales y orquestales representó un parteaguas en la música interpretada hasta entonces en la Catedral de México; formas externas y nuevas de escribir e interpretar la música que, en el caso de los versos para instrumentos, convivieron a su vez con los versos organísticos improvisados paralelamente en las celebraciones, los cuales, al igual que los versos para instrumentos de los siglos anteriores, estaban más apegados a la tradición polifónica y contrapuntística de la música. Así, estos manuscritos de Jerusalem y Stella trazaron una variante en la tradición oral de la música que había llegado con la vieja práctica alternatim de la liturgia; variante que en pleno siglo xviII fue bien recibida y difundida por sus contemporáneos, y tuvo su auge en el siglo XIx.

\section{La noción de "historia" y "género" en los versos instrumentales 56}

Desde finales del siglo xIx, gracias a la invención del gramófono, el acto de escuchar música se ha separado de su dimensión espacial. Esto, junto con la misma escritura musical y la invención de la imprenta, han hecho que el compositor, el ejecutante y el oyente hayan perdido en gran parte el control de su relación con el espacio acústico y, sobre todo, el acto social para el cual la música fue creada. En el caso de los versos instrumentales, es especialmente importante tomar en cuenta la integración de dichas tipologías al espacio, el discurso teoló-

Ve. Sor Dean y Cav.do / Año de I75I. Escrito por Juan de Peñaranda. ACCMm. Tanto el Diario manual, escrito en 175 I como El costumbrero, escrito 68 ańos después, son una especie de manuales relatores del calendario litúrgico que se llevaba a cabo en aquella época en la Catedral de México. Redactados con el fin práctico de cometer las menores faltas posibles en las celebraciones, contienen descripciones sumamente valiosas que nos acercan hoy día a las costumbres y ritos que se llevaban a cabo en el ciclo representado por el oficio y la misa, repetido cada siete días con la interpretación del salterio.

56. En este sentido es necesario rescatar la ayuda observación de Octavio Paz, respecto a que "La obra se cierra al autor y se abre al lector. Las obras no responden a las preguntas del autor sino a las del lector[...] Una vez escrita, la obra tiene una vida distinta a la del autor: la que le otorgan sus lectores sucesivos", en Octavio Paz, Sor Juana Inés de la Cruz o las trampas de la fe (México: Fondo de Cultura Económica, I982), I4. 
DOI: http://dx.doi.org/10.22201/iie.18703062e.2014.105.2529

LOS VERSOS INSTRUMENTALES DE IGNACIO JERUSALEM

gico y la representación de la liturgia, pues, además de su alternancia con versos salmódicos que definían su forma y tono, los versos para instrumentos se alternaban a su vez espacialmente ${ }^{57}$ con tipologías musicales de las que apenas han sobrevivido referencias indirectas, como lo son la improvisación de versos para órgano provenientes de la tradición oral.

Tanto en sus inicios como posteriormente dentro de la Catedral de México, a partir de Ignacio Jerusalem y Stella, podemos encontrar una transformación estilística de los versos a lo largo de los siglos. Sin embargo, también existe una estructura "fija" basada en el marco para el que se creó dicha música: la liturgia de la Iglesia; de tal forma que si tomamos como apoyo estructural para la música litúrgica en la Nueva España la llamada "historia de la música occidental", nos encontramos con un aparente anacronismo que coloca la música colonial a la zaga de las innovaciones europeas, como se ha llegado a manejar en investigaciones pioneras de la música catedralicia de la Nueva España. En el muy particular caso de los versos instrumentales, llama la atención cómo a éstos se les han considerado en algunas publicaciones como parte del declive en la vida musical de las capillas catedralicias, ${ }^{58}$ lo que los ha colocado dentro de una escala comparativa que incluye las llamadas "obras maestras" del occidente europeo. También se han descrito como tipologías que reflejan una búsqueda de los orígenes del movimiento sinfónico en México en el siglo xx, ${ }^{59} \mathrm{e}$ incluso como un género que se originó en la Nueva España. ${ }^{60}$ Por esto último, cabe señalar que el hecho de que, en México, el interés por la investigación e interpretación de la música de nuestro pasado haya surgido a raíz de los movimientos nacionalistas de música a mediados del siglo Xx indica cuán fuertemente está involucrada la sociedad contemporánea en el nombramiento de su historia, de tal forma que la intención por redefinir una identidad en la música de concierto mexicana inevitablemente la encauzó hacia su pasado.

57. Al decir "espacialmente", me refiero a la alternancia de los versos en ambos órganos de la Catedral de México: "el segundo salmo, se cantará acompañado de los órganos verso a verso, por cada uno de los lados del coro" (El costumbrero de la Catedral de México I8I9, escrito por el sochantre P. Vicente Gómez, 83). Esto es consecuencia de un ámbito hispano-portugués, en donde los espacios catedralicios tienen la presencia de dos órganos, uno frente a otro.

58. Robert Stevenson, Music in Mexico, a Historical Survey (Nueva York: Thomas Y. Crowell, I952), I73.

59. Bellinghausen, "El verso: primera manifestación orquestal en México", 4.

6o. Eugenia Roubina, Los instrumentos de arco en la Nueva España (México: Consejo Nacional para la Cultura y las Artes-Fondo Nacional para la Cultura y las Artes, I999), I92. 
DOI: http://dx.doi.org/10.22201/iie.18703062e.2014.105.2529

I 20

JAZMÍN RINCÓN

MAITINES - es la hora canónica más larga y elaborada de todas.

Con negritas: la alternancia de los versos

I. Oraciones preliminares: Pater noster, Ave, María, Credo (en secreto)

2. Invocación

3. Invitatorio

4. Himno

5. Ier Nocturno:

a) 3 antífonas con sus salmos correspondientes —en los maitines mencionados en el Diario manual dice que deben ser "semitonados", es decir, que no se utiliza la fórmula salmódica y, por tanto, tampoco los versos para instrumentos; la "música" consiste entonces en recitar elevando la voz. Así, cuando en los manuscritos se especifica que son para maitines, muy probablemente se trata de fiestas de especial importancia.

b) Verso, respuesta y Pater noster

c) 3 lecturas bíblicas con sus respectivos responsorios (o villancicos)

6. $2^{\circ}$ Nocturno:

d) 3 antífonas con sus salmos correspondientes

e) Verso, respuesta y Pater noster

f) 3 lecturas bíblicas con sus respectivos responsorios (o villancicos)

7. 3er. Nocturno:

g) 3 antífonas con sus salmos correspondientes

h) Verso, respuesta y Pater noster

i) 3 lecturas bíblicas con sus respectivos responsorios (o villancicos)

j) Himno

k) Oración

1) Bendición y despedida

8. Los versos para instrumentos en el oficio de maitines (reconstrucción).

TERCIA - forma parte, junto con prima, sexta y nona, de las horas menores, lo que significa que no es obligación acudir a la iglesia a esta hora.

Con negritas: la alternancia de los versos

I. Oraciones preliminares: Pater noster, Ave María.

2. Invocación: Deus in adjutorium meum...

3. Himno: Nunc Sancte nobis Spiritus...

4. I antífona y tres salmos

Antífona I + Salmo I (alternado con versos instrumentales)

Salmo 2

Salmo 3 (los versos cantados acompańados por los órganos y alternado con versos instrumentales y organísticos)

Repetición de la antífona

5. Lectura breve: Capitulum

6. Responsorio breve

7. Oración

8. Bendición y despedida

9. Los versos para instrumentos en el oficio de tercia (reconstrucción). 
DOI: http://dx.doi.org/10.22201/iie.18703062e.2014.105.2529

LOS VERSOS INSTRUMENTALES DE IGNACIO JERUSALEM

VÍSPERAS —en las grandes fiestas y en los domingos, las vísperas se celebran dos veces, el día anterior a la fiesta y la tarde del mismo día. Esta reconstrucción de vísperas corresponde a las vísperas de los domingos ordinarios.

Negritas: La alternancia de los versos

I. Oraciones preliminares: Pater noster, Ave María

2. Invocación: Deus, in adjutorium meum...

3. 5 antífonas y 5 salmos

Antífona I + Salmo I

Antífona $2+$ Salmo 2

Antífona $3+$ Salmo 3

Antífona $4+$ Salmo 4

Antífona 5 + Salmo (alternado con versos instrumentales)

4. Lectura breve: Capitulum

5. Himno (se alterna con versos instrumentales)

6. Versículo y respuesta

7. Antífona antes del Cantíco

8. Cántico de la Virgen María: Magnificat (alternado con versos instrumentales)

9. Preces

Io. Oración

I I. Sufragio: invocación a todos los santos (antífona, versículo, oración)

I2. Conmemoración de la Santa Cruz (en tiempo de Pascua)

I3. Oración

I4. Bendición y despedida

ı. Los versos para instrumentos en el oficio de vísperas.

Sin embargo, este mismo deseo de nacionalismo y búsqueda de lo "mexicano" ha repercutido en las investigaciones de la música conservada en los archivos catedralicios, e incluso ha llegado a generar cadenas de lecturas erróneas que se han visto reflejadas, tanto en la edición musical, como en la práctica interpretativa ${ }^{6 \mathrm{r}}$ Esto último tampoco es exclusivo de la historiografía musical en México, pues en las últimas décadas, en el ámbito global, se ha enfatizado la importancia de articular el punto de vista del investigador, con el argumento de que el acto de interpretar es inherente, no sólo a las fuentes primarias, sino también al entorno,

6I. Juan Francisco Sans, "Ni son anónimas ni son instrumentales ni están inéditas: las sonatas del Archivo de Música de la Catedral de México", Heterofonía, núm. I38-1 39 (enerodiciembre, 2008): I 3I-I 53. 
deseos y necesidades de los que la estudian actualmente. ${ }^{62}$ Además, el hecho de que interpretar sea un acto en el cual intervenimos se ha visto reflejado en los procesos de selección histórica que se han dado en la música occidental, en la cual se han promovido y valorado más obras con características innovadoras; ${ }^{63}$ obras convencionales y de especial carácter práctico-ritual, como es el caso de los presentes versos para instrumentos, suelen quedarse al margen de la llamada "historia de la música" aún vigente en el ámbito institucional.

Así, la necesidad de nombrar y clasificar ha sido siempre fundamental para el entendimiento de un lenguaje; la sociedad novohispana eligió y codificó su lenguaje musical de acuerdo a su entorno y necesidades, lo cual explica que la existencia y transformación en catedrales e iglesias menores de un género como los versos para instrumentos se encuentren aunadas a un contexto sociocultural, devocional y discursivo.

62. En el campo de la edición musical, las ediciones Urtext, cuyo objetivo original era proporcionar textos que permitiesen que la notación de los compositores hablara por sí misma, tuvieron que reconocer igualmente la necesidad de articular el punto de vista crítico del editor e investigador. También podemos encontrar un equivalente en el campo de la ejecución de la música del pasado, con el surgimiento y transformación del movimiento de interpretación histórica (HIP-Historically Informed Performance).

63. Esto se desprende del hecho de que el arte occidental se ha distinguido de las otras grandes tradiciones artísticas por el lugar reservado a la innovación, a la originalidad, a lo nunca visto u oído, hasta el punto de que en el siglo xix surgió la idea de vanguardia artística, movimiento que se articularía en torno al futuro. 
DOI: http://dx.doi.org/10.22201/iie.18703062e.2014.105.2529

LOS VERSOS INSTRUMENTALES DE IGNACIO JERUSALEM

Anexo

Reconstrucción del juego de versos Ao591.0 I, con el salmo i I2 Laudate, pueri, Dominum. ${ }^{64} \mathrm{Al}$ tener el salmo diez versos, utilizo sólo cuatro de los versos instrumentales en alternatim. Un salmo con más versos, como el I I 3 In exitu Israël que contiene 29 hubiese permitido la inclusión de todos los versos. Sin embargo, debido a que eran los versos para instrumentos los que se adaptaban a la longitud del salmo y no al revés, es por lo que los mantengo de esta forma:
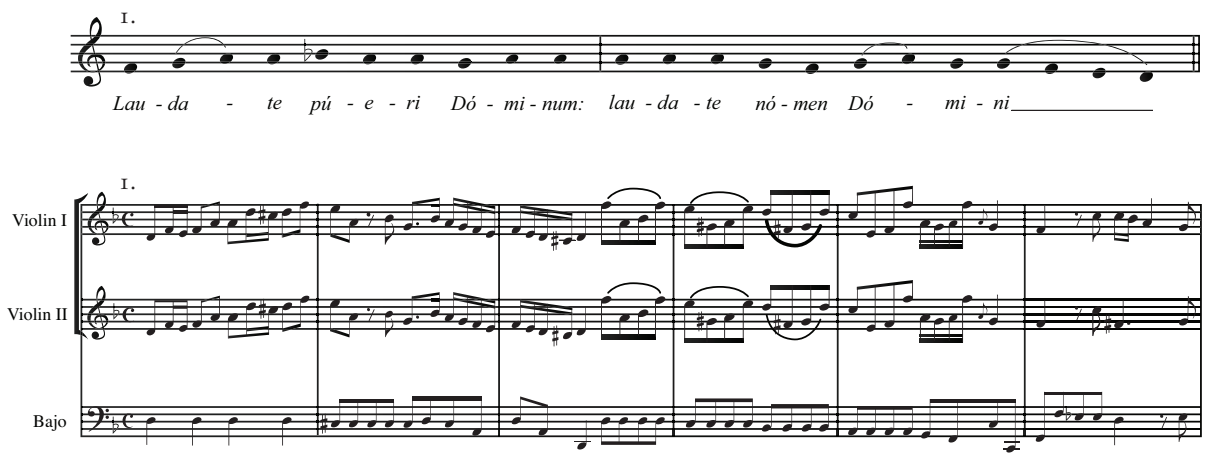

64. Tomado de: Liber Usualis, Missae et officii pro dominicis et festis cum cantu gregoriano ex ceditione vaticana adamussim excerpto (Bélgica: Sedis Apostolica et Sacrorum Rituum Congregationis Typographi, I956), I66. Trad: I. ¡Aleluya! Alaben, siervos del Señor, / alaben el Nombre del Señor. / 2. Bendito sea el Nombre del Seńor / ahora y por siempre. / 3. Desde la salida del sol hasta su ocaso, / alabado sea el Nombre del Señor. / 4. El Señor es excelso sobre todos los pueblos, / su gloria sobre los cielos. / 5. ¿̨uién como el Señor, Dios nuestro, / que está entronizado en lo alto / 6. y se inclina para mirar / desde el cielo a la tierra? / 7. Levanta del polvo al desvalido, / ala de la basura al pobre, / 8. para sentarlo con los nobles, / con los más nobles de su pueblo. / 9. Pone al frente de su casa / a la estéril, madre feliz de hijos. ¡Aleluya! (La biblia de nuestro pueblo, trad. Luis Alonso Schökel [Bilbao: Ediciones Mensajero], Salmos I I 3, I 2 .

N.B. El presente artículo forma parte de mi tesis de investigación que llevo a cabo en el Doctorado en Historia del Arte de la Universidad Nacional Autónoma de México, titulada: "Los versos instrumentales: historia y función de un género musical en la Catedral de México". Las partituras del "Ane rus" las redibujó Citlali Coronel. 
DOI: http://dx.doi.org/10.22201/iie.18703062e.2014.105.2529

I 24

JAZMÍN RINCÓN
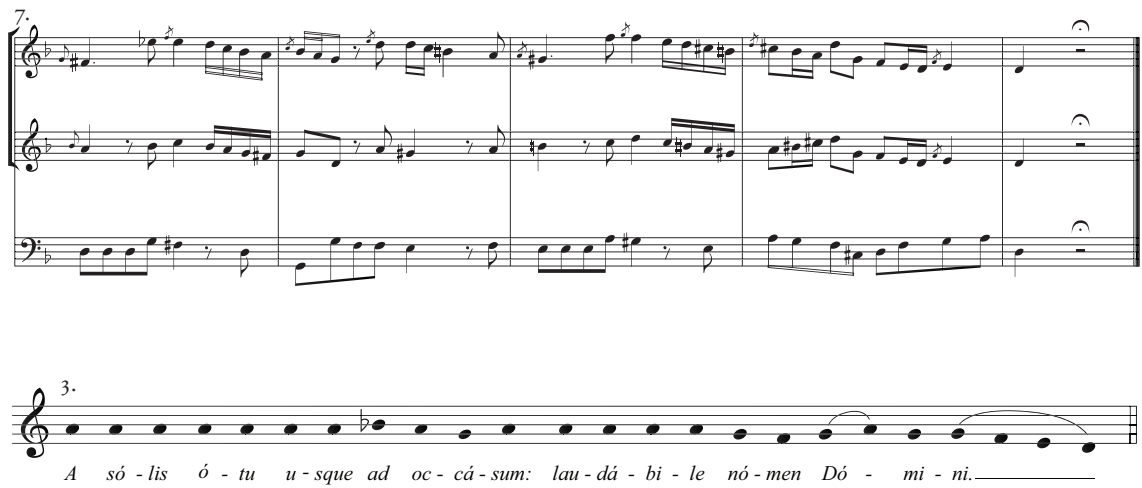

2.
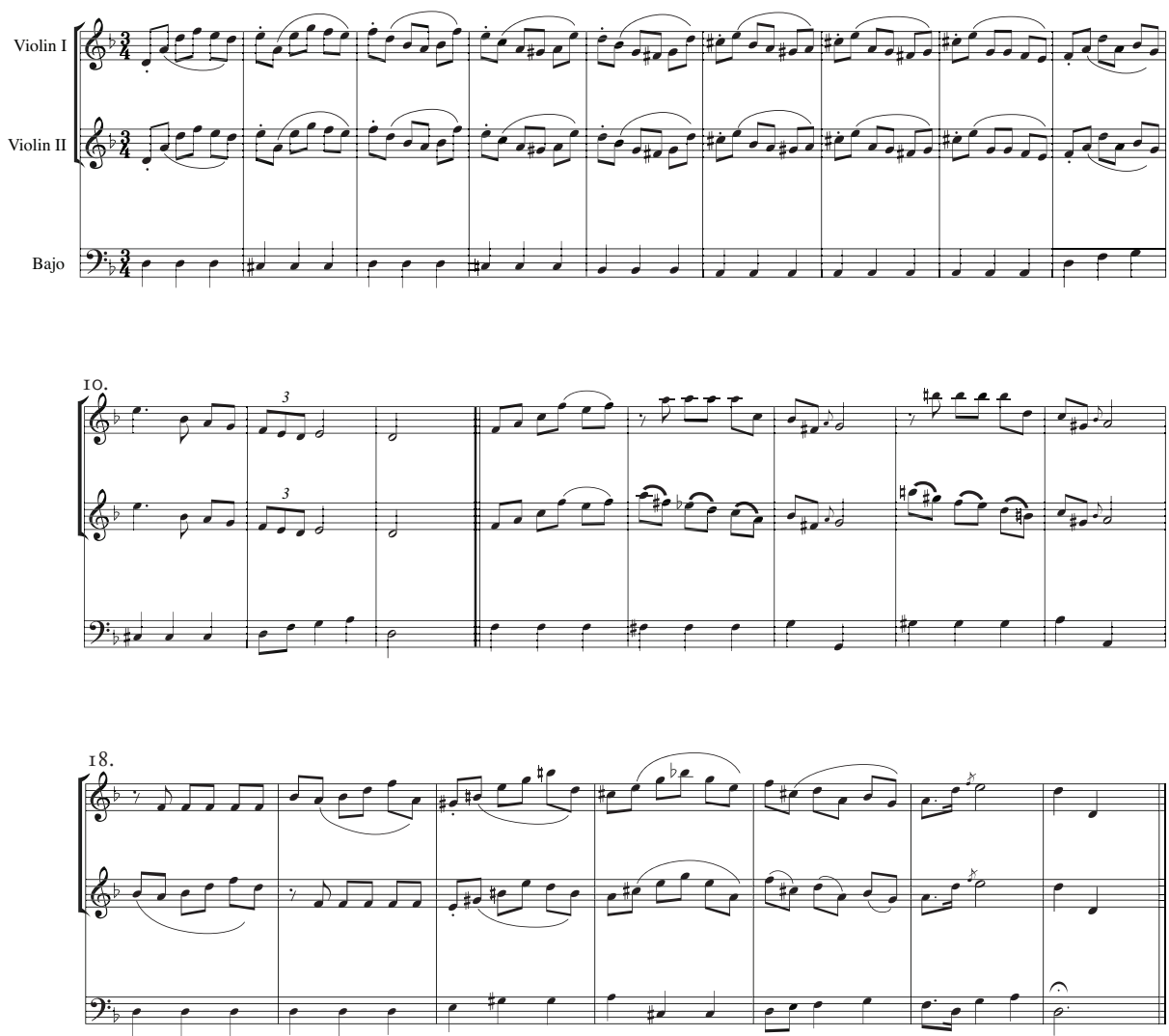
DOI: http://dx.doi.org/10.22201/iie.18703062e.2014.105.2529

LOS VERSOS INSTRUMENTALES DE IGNACIO JERUSALEM
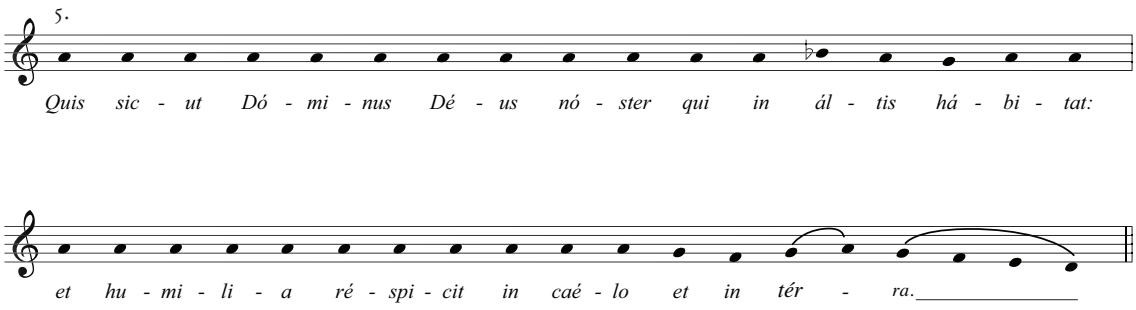

3.
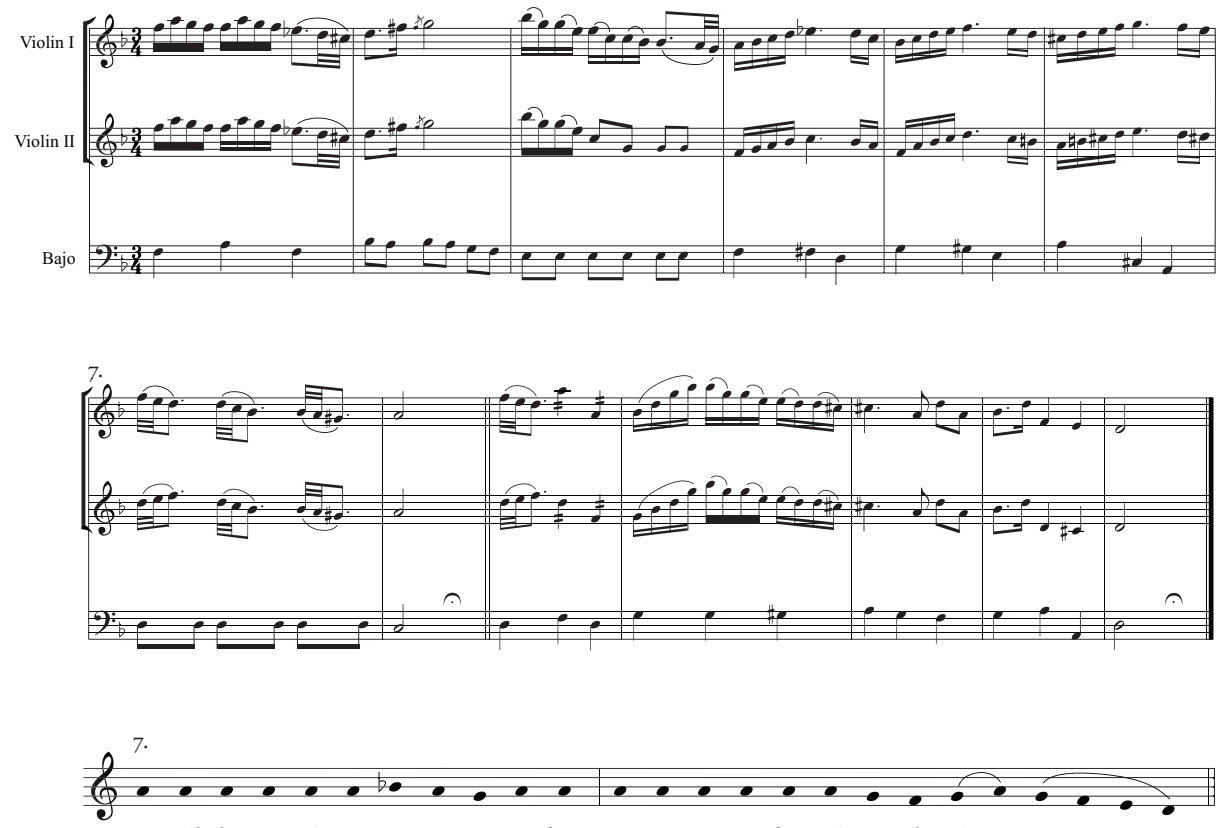

Ut cól-lo-cet é-um cumprin-ci-pi-bus: cumprin-ci-pi-bus pó-pu-li sú - $i$

4.

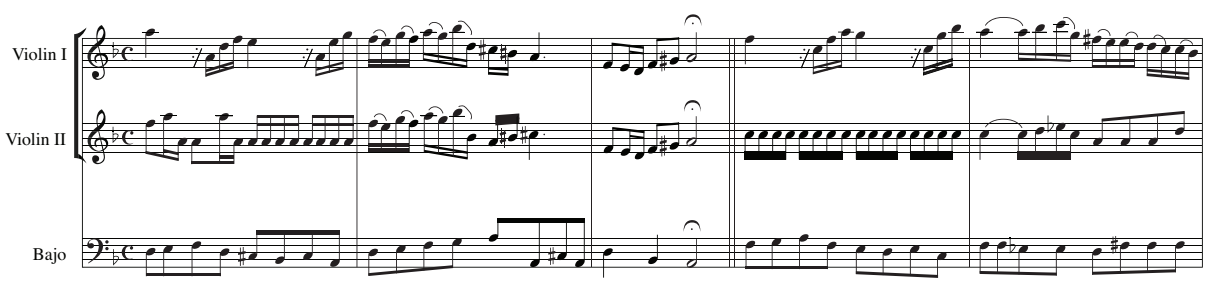


DOI: http://dx.doi.org/10.22201/iie.18703062e.2014.105.2529

I 26 JAZMÍN RINCÓN
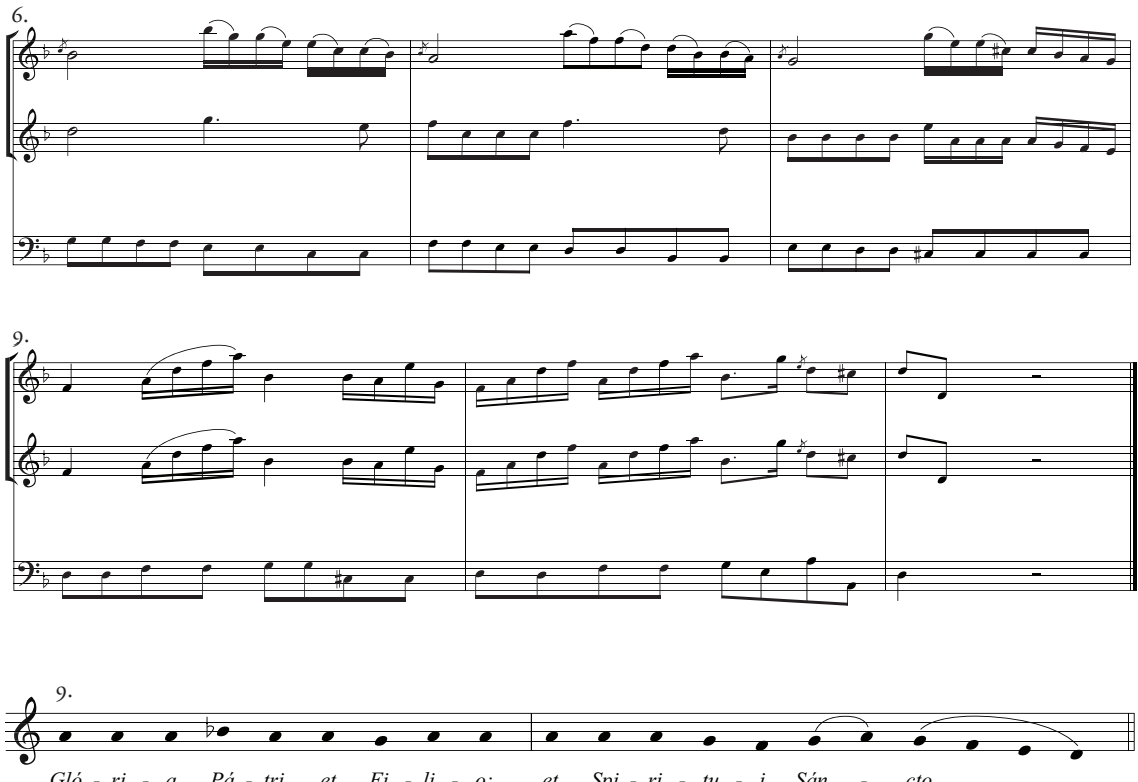
Gló - ri - a Pá - tri et Fi - li - o et Spi-ri-tu - i Sán - cto.

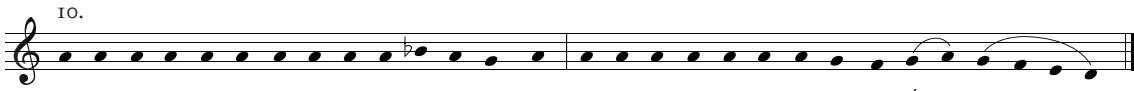

Sic-ut é-rat in prin-ci-pi-o et nunc et sém-per: et in saé-cu-la sae-cu-ló-rum. Á men. 